\title{
Dihydroflavonols from the leaves of Derris urucu (Leguminosae): Structural Elucidation and DPPH Radical-Scavenging Activity
}

\author{
Livia T. Lôbo, ${ }^{a}$ Geilson A. da Silva, ${ }^{a}$ Malisson Ferreira, ${ }^{a}$ Milton N. da Silva, ${ }^{a}$ Alberdan S. Santos, ${ }^{a}$ \\ Alberto C. Arruda, ${ }^{a}$ Giselle M. S. P. Guilhon, ${ }^{a}$ Lourivaldo S. Santos, ${ }^{a}$ Rosivaldo dos Santos Borges ${ }^{b}$ \\ and Mara Silvia P. Arruda*,a
}

\author{
aPrograma de Pós-Graduação em Química, Instituto de Ciências Exatas e Naturais, Universidade Federal do Pará, \\ Campus Universitário do Guamá, 66075-970 Belém-PA, Brazil \\ ${ }^{b}$ Faculdade de Farmácia, Instituto de Ciências da Saúde, Universidade Federal do Pará, Campus Universitário do \\ Guamá, 66075-970 Belém-PA, Brazil
}

\begin{abstract}
Derris urucu é uma planta da Amazônia com propriedades inseticida e ictiotóxica. Estudos com esta espécie reportam a presença de flavonóides, principalmente rotenóides, bem como de estilbenos. A partir do extrato etanólico das folhas de Derris urucu (Leguminosae), três novos diidroflavonóides, denominados urucuol A (1), B (2) e C (3) e o diidroflavonol isotirumalina (4), foram isolados e identificados. As estruturas destes compostos foram elucidadas por uma extensiva análise espectroscópica de RMN uni e bidimensional, UV, IV e dados de EM, além de comparação com dados da literatura. Os compostos isolados (1-4) foram avaliados quanto ao seu potencial sequestrador do radical $\mathrm{DPPH}^{\bullet}$ e apresentaram baixo poder antioxidante quando comparados ao antioxidante comercial trans-resveratrol.
\end{abstract}

Derris urucu is an Amazonian plant with insecticide and ichthyotoxic properties. Studies with this species show the presence of flavonoids, mainly rotenoids, as well as stilbenes. The ethanol extract of the leaves of Derris urucu (Leguminosae) afforded three new dihydroflavonols named urucuol A (1), B (2) and C (3), and the dihydroflavonol isotirumalin (4). Their structures were elucidated by extensive analysis of $1 \mathrm{D}$ and $2 \mathrm{D}$ NMR, UV and IR spectra and MS data and comparison with literature data. The isolated compounds (1-4) were evaluated for DPPH' radical scavenging activity and showed a relatively lower antioxidant ability compared to the commercial antioxidant trans-resveratrol.

Keywords: Derris urucu, Leguminosae, dihydroflavonols, radical scavenging activity, antioxidant

\section{Introduction}

Amazonian ecosystems are rich in plants with insecticide and piscicide properties, and those belonging to the Derris genus are the most used. ${ }^{1}$ These plants, in the Amazon area, are called "timbó". Some studies carried out on roots of Derris urucu extracts related the presence of rotenoids, especially rotenone, that show insecticide and ichthyotoxic activity. ${ }^{2-5}$ In addition to rotenoids, others minor flavonoids, such as flavanones, isoflavanones and chalcones, together with stilbenes, have been also described from the roots of Derris urucu. ${ }^{6}$ Flavonoids belong to a group of naturally occurring compounds with a number of

*e-mail: mspa@ufpa.br biological activities, such as antibacterial, antimutagenic, cytotoxic and anticarcinogenic, ${ }^{7-10}$ together with antioxidant activity, which is one of the most studied. ${ }^{11,12}$ Antioxidant activity arises from the ability of flavonoids to scavenge free radicals and thus eliminate reactive oxygen species. ${ }^{13,14}$ These phenolic compounds are known to possess an antioxidant character to various extents. ${ }^{15-17}$ Therefore, the antioxidant activity of these natural compounds is related to a number of different mechanisms such as free radical scavenging, hydrogen donation, singlet oxygen quenching, metal ion chelation, and acting as a substrate for radicals such as superoxide and hydroxide. ${ }^{18}$ Because oxidative stress is known to cause many diseases, scientists have become more interested in natural sources to fight it, looking for active components from plants in recent years. 
Nevertheless, some phenolic compounds increase oxidative stress and toxicity because of their prooxidant properties. ${ }^{19}$ The balance between antioxidant or prooxidant properties can be determined by the scavenger capacity of radical oxygen or nitrogen species using spectrophotometric methods, such as DPPH, which has been applied to the phenolic compounds commonly present in natural products. The spectrophotometric technique employs the 1,1-diphenyl-2-picrylhydrazyl free radical (DPPH'), which shows a characteristic UV-Vis spectrum with a maximum of absorbance close to $517 \mathrm{~nm}$ in methanol. The addition of an antioxidant compound results in a decrease of absorbance proportional to the concentration and antioxidant activity of the compound..$^{20}$ This method presents the advantage of the use of a stable and commercially available free radical and has been extensively applied to the study of antioxidant activity of food items, such as olive oil, fruits, juices and wines. ${ }^{21-26}$ It is easy to perform, highly reproducible and comparable with other methods such as ABTS, reduction of superoxide anion and inhibition of lipid peroxidation. ${ }^{27,28}$ In particular, DPPH free radical has been used to assess the ability of phenolic compounds to transfer labile $\mathrm{H}$ atoms to radicals. ${ }^{29}$ Total $\mathrm{H}$ atom donating capacities are evaluated in the $\mathrm{EC}_{50}$ index, defined as the concentration needed to reduce $50 \%$ of $\mathrm{DPPH}^{\cdot}$ free radical.

Thus, in this work we have investigated leaves of $D$. игиси for the first time, searching for compounds with potential antioxidant activity, resulting in the isolation of three new dihydroflavonols named urucuol A (1), B (2) and $\mathrm{C}(\mathbf{3})$, as well as dihydroflavonol isotirumalin (4) (Figure 1), which were evaluated for the ability of DPPH ${ }^{\circ}$ radical-scavenging. Our purpose in this work was also contribute to a better understanding of the mechanistic features of antioxidant processes of the dihydroflavonols isolated from Derris urucu.

\section{Results and Discussion}

The dried leaves of Derris urucu were extracted with EtOH. The ethanolic extract was fractionated by silica gel column chromatography affording six fractions. Chromatographic separation of the EtOAc-soluble fraction by semi-preparative HPLC led to the purification of pure substances 1-4 (Figure 1).

The UV spectra of these compounds showed similar behavior, with maxima of $\lambda 229-235,261-291$, and 309342 (sh) nm, corresponding to the $\pi \rightarrow \pi *$ and $\mathrm{n} \rightarrow \pi *$ transitions, that matched the dihydroflavonol skeletons. ${ }^{30}$ The IR spectra of the isolated compounds showed a similar series of absorption bands at $v_{\max } 3458-3206 \mathrm{~cm}^{-1}$, corresponding to $\mathrm{OH}$ vibrations; $2974-2933 \mathrm{~cm}^{-1}$, corresponding to $\mathrm{CH}$ vibrations; $1633-1597 \mathrm{~cm}^{-1}$, corresponding to $\mathrm{C}=\mathrm{O}$ vibrations and $1574-1434 \mathrm{~cm}^{-1}$, corresponding to $\mathrm{C}=\mathrm{C}$ vibrations, of the aromatic ring. ${ }^{30}$

Compound $\mathbf{1}$ was obtained as a pale yellow powder. Its ESI mass spectrum in the positive mode exhibited a high intensity ion peak at $\mathrm{m} / z, 407[\mathrm{M}+\mathrm{Na}]^{+}$and smaller ion peaks at $m / z 385[\mathrm{M}+\mathrm{H}]^{+}, 325\left[\mathrm{M}+\mathrm{Na}-58\left(\mathrm{C}_{3} \mathrm{H}_{6} \mathrm{O}\right)-\mathrm{H}\right]^{+}$, $284\left[\mathrm{M}+\mathrm{H}-58\left(\mathrm{C}_{3} \mathrm{H}_{6} \mathrm{O}\right)-28(\mathrm{CO})-15\left(\mathrm{CH}_{3}\right)\right]^{+}$and 236 . The molecular formula $\mathrm{C}_{21} \mathrm{H}_{20} \mathrm{O}_{7}$ was determined by HRESIMS at $m / z 407.1126[\mathrm{M}+\mathrm{Na}]^{+}$(calc. for $\mathrm{C}_{21} \mathrm{H}_{20} \mathrm{O}_{7} \mathrm{Na}, 407.1107$ ). Its ${ }^{1} \mathrm{H}$ NMR spectrum (Table 1 ) exhibited a typical AX system due to $\mathrm{H}-2$ and $\mathrm{H}-3$ of a dihydroflavonol ${ }^{31}$ at $\delta_{\mathrm{H}}$ $4.96(d, J 12.0 \mathrm{~Hz})$ and $4.51(d, J 12.0 \mathrm{~Hz})$, respectively. These assignments were confirmed by the ${ }^{13} \mathrm{C}$ NMR spectrum (Table 2), which showed three C-ring carbon signals at $\delta_{\mathrm{C}} 83.1(\mathrm{C}-2), 72.3(\mathrm{C}-3)$ and $195.9(\mathrm{C}-4)$. The configuration at $\mathrm{C}_{2-} \mathrm{C}_{3}$ was determined to be trans on the basis of the magnitude of ${ }^{3} J_{\mathrm{H} 2-\mathrm{H} 3} 12 \mathrm{~Hz} .{ }^{32}$ Besides, the ${ }^{1} \mathrm{H}$ NMR spectrum exhibited signals in the aromatic region at $\delta_{\mathrm{H}} 7.14(1 \mathrm{H}, d, J 1.8 \mathrm{~Hz}), 7.02(1 \mathrm{H}, d d, J 8.1 \mathrm{e} 1.8 \mathrm{~Hz})$ and $6.91(1 \mathrm{H}, d, J 8.1 \mathrm{~Hz})$, which indicated a AMX spin system of a 1,3,4-trisubstituted phenyl group, as well as one singlet at $\delta_{\mathrm{H}} 5.96$ attributed to a pentasubstituted aromatic ring proton. The signals observed at $\delta_{\mathrm{H}} 6.62$ and $5.62(1 \mathrm{H}$ each, $d, J 10.2 \mathrm{~Hz})$ and $1.44(6 \mathrm{H}, s)$ revealed a 2,2-dimethylchromeno ring attached to an aromatic ring, and the singlets at $\delta_{\mathrm{H}} 11.45$ and 3.92 indicated the presence of a quelated hydroxyl to carbonyl and one OMe group connected to the aromatic ring, respectively.
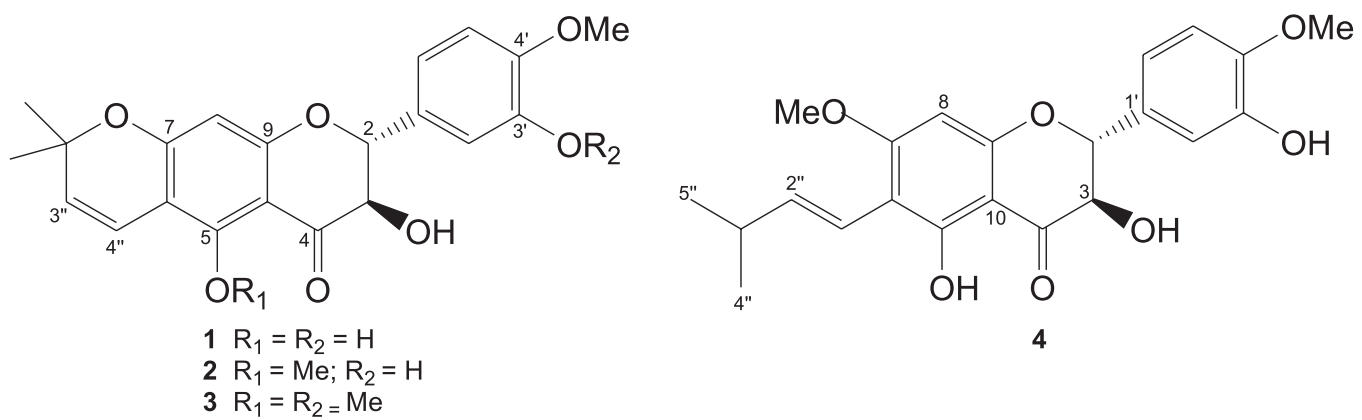

Figure 1. Structures of the new dihydroflavonols isolated from leaves of the Derris urucu: urucuol A (1), urucuol B (2), urucuol C (3) and isotirumalin (4). 
All the couplings were confirmed through the analysis of ${ }^{1} \mathrm{H}-{ }^{1} \mathrm{H}$ COSY spectrum. In addition to the signals related to C-ring carbons, the ${ }^{13} \mathrm{C}$ NMR spectrum of $\mathbf{1}$ exhibited other 17 signals attributed to eighteen carbons with aid of the HETCOR and HMBC (Table 2) experiments. The 2,2-dimethylchromene ring attached to the A ring at C-6 and C-7 was deduced by ${ }^{3} \mathrm{~J}_{\mathrm{C}, \mathrm{H}}$ correlations from $\mathrm{H}-3^{\prime \prime}, \mathrm{H}-8$ and $\mathrm{OH}-5$ to $\mathrm{C}-6$. The location of the $\mathrm{OMe}$ and $\mathrm{OH}$ groups at $\mathrm{C}-4^{\prime}$ and $\mathrm{C}-3^{\prime}$ of the aromatic B-ring, respectively, was supported by the combination of the substitution pattern on the aromatic ring (1,3,4-trisubstituted) observed in the ${ }^{1} \mathrm{H}$ NMR spectrum with the ${ }^{2,3} J_{\mathrm{C}, \mathrm{H}}$ correlations from $\mathrm{H}-6$ ', $\mathrm{H}-5^{\prime}, \mathrm{H}-2^{\prime}$ and $\mathrm{OMe}-4^{\prime}$ to oxidized aromatic carbon C-4' $\left(\delta_{\mathrm{C}} 147.3\right)$ and from both $\mathrm{H}-5^{\prime}$ and $\mathrm{H}-2^{\prime}$ to another oxidized aromatic carbon $\mathrm{C}-3^{\prime}\left(\delta_{\mathrm{C}} 145.8\right)$. Therefore, the structure of 1 was determined as $(2 R, 3 R)-5,3^{\prime}$-dihydroxy-4'-methoxy$6^{\prime \prime}, 6^{\prime \prime}$-dimethylpyrano[ $\left[2^{\prime \prime}, 3^{\prime \prime}: 7,6\right]$ dihydroflavonol, which we named urucuol A. The spectral analysis clearly indicated that 1 is isomeric with $(2 R, 3 R)-5,4^{\prime}$-dihydroxy- $3^{\prime}$ methoxy-6",6"-dimethylpyrano[2", 3":7,6]dihydroflavonol (eritrinol). ${ }^{33}$

Compound 2 was obtained as a yellow amorphous powder. Its positive ESI-MS fragmentation pattern is similar to that urucuol A (1), exhibiting ion peaks at $m / z 421$ $[\mathrm{M}+\mathrm{Na}]^{+}, 399[\mathrm{M}+\mathrm{H}]^{+}, 325\left[\mathrm{M}+\mathrm{Na}-58\left(\mathrm{C}_{3} \mathrm{H}_{6} \mathrm{O}\right)-15\left(\mathrm{CH}_{3}\right)\right]^{+}$, $284\left[\mathrm{M}+\mathrm{H}-58\left(\mathrm{C}_{3} \mathrm{H}_{6} \mathrm{O}\right)-28(\mathrm{CO})-28(\mathrm{CO})-\mathrm{H}\right]^{+}$and 236. The ion peaks at $m / z, 421$ and 399 are 14 mass units more than the corresponding peaks in $\mathbf{1}$, suggesting one additional Me group. These data, together with the ${ }^{1} \mathrm{H}$ and ${ }^{13} \mathrm{C}$ NMR data, have allowed us to consider a molecular formula of $\mathrm{C}_{22} \mathrm{H}_{22} \mathrm{O}_{7}$ for 2, confirmed by HRESIMS at $m / z 421.1285[\mathrm{M}+\mathrm{Na}]^{+}$(calc. for $\mathrm{C}_{22} \mathrm{H}_{22} \mathrm{O}_{7} \mathrm{Na}, 421.1263$ ). The ${ }^{1} \mathrm{H}$ and ${ }^{13} \mathrm{C}$ NMR data of compound 2 were very similar to those reported for $\mathbf{1}$, indicating the presence of 1,3,4-trisubstituted and pentasubstituted aromatic rings, and still a gem-dimethylchromene ring. The main differences between the spectroscopic data of $\mathbf{1}$ and $\mathbf{2}$ are signals for two OMe groups at $\delta_{\mathrm{H}} 3.91$ and 3.88, instead one OMe singlet as in $\mathbf{1}$, which showed correlations with the OMe signals at $\delta_{\mathrm{C}} 55.9$ and 62.6, respectively, in the HETCOR spectrum. The last value is typical of a di-ortho-substituted OMe group, ${ }^{34}$ which was located at C-5. This information and HMBC correlations between H-8 and two oxidized aromatic carbons (C-7 and C-9) and two substituted aromatic carbons (C-6 and C-10), as well the correlations between both $\mathrm{H}-3^{\prime \prime}$ and $\mathrm{H}-4^{\prime \prime}$ and C-6, confirmed the gem-dimethylchromene moiety placed at C-6/C-7. Analogous to compound 1, 2 possesses a 4'-OMe and 3'-OH substituted B-ring. This was confirmed by the ${ }^{2,3} J_{\mathrm{C}, \mathrm{H}}$ correlations from $\mathrm{H}-6^{\prime}$ and $\mathrm{H}-2^{\prime}$ to $\mathrm{C}-4^{\prime}\left(\delta_{\mathrm{C}} 147.2\right)$ and from $\mathrm{H}-5^{\prime}$ and $\mathrm{H}-2^{\prime}$ to $\mathrm{C}-3^{\prime}\left(\delta_{\mathrm{C}} 145.8\right)$. The trans configuration at $\mathrm{C}_{2}-\mathrm{C}_{3}$ was deduced from the coupling constant $(J 12.0 \mathrm{~Hz})$ between $\mathrm{H}-2$ and $\mathrm{H}-3$. On this basis 2 was unambiguously identified as $(2 R, 3 R)-3^{\prime}$-hydroxy$5,4^{\prime}$-dimethoxy-6", $6^{\prime \prime}$-dimethylpyrano $\left[2^{\prime \prime}, 3^{\prime \prime}: 7,6\right]$ dihydroflavonol, named urucuol B.

Compound $\mathbf{3}$ was also isolated as a yellow amorphous powder and showed spectral characters similar to urucuol A (1) and urucuol B (2). The ESI-MS in the positive mode of $\mathbf{3}$ presented a fragmentation pattern analogous to both $\mathbf{1}$ and $\mathbf{2}$, exhibiting an ion peak at $m / z 435[\mathrm{M}+\mathrm{Na}]^{+}$and a quasi molecular ion at $m / z 413[\mathrm{M}+\mathrm{H}]^{+}$, which are 28 and 14 mass units bigger than the respective peaks of $\mathbf{1}$ and $\mathbf{2}$, suggesting two and one additional OMe groups from $\mathbf{1}$ and 2 , respectively, as well as the molecular formula $\left(\mathrm{C}_{23} \mathrm{H}_{24} \mathrm{O}_{7}\right)$ for 3, confirmed by HRESIMS at $m / z 435.1440[\mathrm{M}+\mathrm{Na}]^{+}$ (calc. for $\mathrm{C}_{23} \mathrm{H}_{24} \mathrm{O}_{7} \mathrm{Na}, 435.1420$ ). Comparison of the ${ }^{1} \mathrm{H}$ and ${ }^{13} \mathrm{C}$ NMR spectral data of $\mathbf{3}$ with $\mathbf{2}$ (Table 1 and 2) fully supported the same groups and substitution pattern for the $\mathrm{A}$ and $\mathrm{C}$ rings in both compounds.

The difference between compounds $\mathbf{2}$ and $\mathbf{3}$ is an extra OMe group located at C-3', confirmed by the ${ }^{3} J_{\mathrm{C}, \mathrm{H}}$ correlations observed between H-6 $\left(\delta_{\mathrm{H}} 7.09\right)$ and OMe$4^{\prime}\left(\delta_{\mathrm{H}} 3.90\right)$ with $\mathrm{C}-4^{\prime}\left(\delta_{\mathrm{C}} 149.7\right)$, and from both $\mathrm{H}-5^{\prime}$ $\left(\delta_{\mathrm{H}} 6.93\right)$ and OMe-3' $\left(\delta_{\mathrm{H}} 3.92\right)$ with $\mathrm{C}-3^{\prime}\left(\delta_{\mathrm{C}} 149.1\right)$. Compound 3 showed a $\mathrm{C}_{2}-\mathrm{C}_{3}$ configuration similar to $\mathbf{1}$ and 2. This allowed the identification of $\mathbf{3}$ as $(2 R, 3 R)$ $5,3^{\prime}, 4^{\prime}$-trimethoxy-6", $6^{\prime \prime}$-dimethylpyrano[2", $\left.3^{\prime \prime}: 7,6\right]$ dihydroflavonol, named urucuol $\mathrm{C}$.

Compound $\mathbf{4}$ was also isolated as a white amorphous powder and its molecular formula was determined to be $\mathrm{C}_{22} \mathrm{H}_{24} \mathrm{O}_{7}$ based on its HRESI-MS at $\mathrm{m} / z 423.1439$ $[\mathrm{M}+\mathrm{Na}]^{+}$(calc. for $\mathrm{C}_{22} \mathrm{H}_{24} \mathrm{O}_{7} \mathrm{Na}, 423.1420$ ). Its positive ESI-MS showed a ion peak at $m / z, 423[\mathrm{M}+\mathrm{Na}]^{+}$and small peaks at $\mathrm{m} / \mathrm{z} 401[\mathrm{M}+\mathrm{H}]^{+}, 345\left[\mathrm{M}+\mathrm{H}-55\left(\mathrm{C}_{4} \mathrm{H}_{7}\right)\right]^{+}$, $325\left[\mathrm{M}+\mathrm{H}-32\left(\mathrm{CH}_{3} \mathrm{OH}\right)-42\left(\mathrm{C}_{3} \mathrm{H}_{6}\right)-\mathrm{H}\right]^{+}, 284[\mathrm{M}+\mathrm{H}-$ $\left.32\left(\mathrm{CH}_{3} \mathrm{OH}\right)-42\left(\mathrm{C}_{3} \mathrm{H}_{6}\right)-28(\mathrm{CO})-15\left(\mathrm{CH}_{3}\right)\right]^{+}$. The presence of a $\gamma, \gamma$-dimethylallyl group was evidenced by ${ }^{1} \mathrm{H}$ NMR signals at $\delta_{\mathrm{H}} 3.26\left(d, J 7.2 \mathrm{~Hz}, 2 \mathrm{H}-1^{\prime \prime}\right), 5.17(t, J 7.2$ $\left.\mathrm{Hz}, \mathrm{H}-2^{\prime \prime}\right), 1.68\left(s, 3 \mathrm{H}-4^{\prime \prime}\right)$ and $1.77\left(s, 3 \mathrm{H}-5^{\prime \prime}\right) \cdot{ }^{31,34} \mathrm{An}$ OH-5 quelated signal at $\delta_{\mathrm{H}} 11.23$ was also observed. The aromatic and the C-ring proton signals of $\mathbf{4}$ (Table 1), as well as B and C-ring carbon signals of $\mathbf{4}$ (Table 2) were very similar to those of $\mathbf{1}$. Thus, the difference between $\mathbf{1}$ and $\mathbf{4}$ is in ring A. The $\gamma, \gamma$-dimethylallyl moiety and one OMe group were confirmed to be attached at C-6 and C-7 (A-ring), respectively, based on the long-range correlations from $2 \mathrm{H}-1^{\prime \prime}, \mathrm{H}-8$ and $\mathrm{OH}-5$ to C-6, and 2H-1" and OMe-7 to C-7. From these results, the structure of 4 was identified as $(2 R, 3 R)-5,3^{\prime}$-dihydroxy-6-(3-methylbut2-enyl)-7,4'-dimethoxy-dihydroflavonol, knowed as isotirumalin. ${ }^{35}$ 
Table 1. ${ }^{1} \mathrm{H}$ NMR Chemical Shifts $\left(\delta_{\mathrm{H}}\right.$ in ppm) and Coupling Constants $(J$ in $\mathrm{Hz})$ of Compounds $1-4$ in $\mathrm{CDCl}_{3}{ }^{\mathrm{a}}$

\begin{tabular}{|c|c|c|c|c|}
\hline $\mathrm{H}$ & $\begin{array}{c}1 \\
\delta_{\mathrm{H}} \\
\end{array}$ & $\begin{array}{c}2 \\
\delta_{\mathrm{H}} \\
\end{array}$ & $\begin{array}{c}3 \\
\delta_{\mathrm{H}} \\
\end{array}$ & $\begin{array}{c}4 \\
\delta_{\mathrm{H}} \\
\end{array}$ \\
\hline 2 & $4.96(d, 12.0)$ & $4.93(d, 12.0)^{\mathrm{b}}$ & $4.97(d, 12.0)$ & $4.97(d, 12.0)$ \\
\hline 3 & $4.51(d, 12.0)$ & $4.42(d, 12.0)$ & $4.46(d, 12.0)$ & $4.53(d, 12.0)$ \\
\hline 8 & $5.96(s)$ & $6.21(s)$ & $6.23(s)$ & $6.08(s)$ \\
\hline $2^{\prime}$ & $7.14(d, 1.8)$ & $7.14(d, 2.1)$ & $7.07(d, 2.4)$ & $7.15(d, 1.8)$ \\
\hline $5^{\prime}$ & $6.91(d, 8.1)$ & $6.90(d, 8.1)$ & $6.93(d, 8.7)$ & $6.91(d, 8.1)$ \\
\hline $6^{\prime}$ & $7.02(d d, 8.1$ and 1.8$)$ & $7.02(d d, 8.1$ and 2.1$)$ & $7.09(d d, 8.7$ and 2.4) & $7.03(d d, 8.1$ and 1.8$)$ \\
\hline $1^{\prime \prime}$ & & & & $3.26(d, 7.2)$ \\
\hline $2^{\prime \prime}$ & & & & $5.17(t, 7.2)$ \\
\hline $3^{\prime \prime}$ & $5.52(d, 10.2)$ & $5.62(d, 10.2)$ & $5.62(d, 10.0)$ & \\
\hline $4^{\prime \prime}$ & $6.62(d, 10.2)$ & $6.61(d, 10.2)$ & $6.611 \mathrm{H},(d, 10.0)$ & $1.68(s)$ \\
\hline $5^{\prime \prime}$ & & & & $1.77(s)$ \\
\hline $2 \mathrm{Me}-2^{\prime \prime}$ & $1.44(s)$ & $1.44(s)$ & $1.44(s)$ & \\
\hline OMe-5 & & $3.88(s)$ & $3.89(s)$ & \\
\hline \multicolumn{5}{|l|}{ OMe-6 } \\
\hline OMe-7 & & & & $3.83(s)$ \\
\hline OMe-3' & & & $3.92(s)$ & \\
\hline OMe- $4^{\prime}$ & $3.92(s)$ & $3.91(s)$ & $3.90(s)$ & $3.91(s)$ \\
\hline OH-5 & $11.45(s)$ & & & $11.23(s)$ \\
\hline $\mathrm{OH}-3^{\prime}$ & $5.73(b r s)$ & & & \\
\hline
\end{tabular}

${ }^{\mathrm{a}}{ }^{1} \mathrm{H}$ NMR data were recorded at $300 \mathrm{MHz} .{ }^{\mathrm{b}}$ Multiplicity and coupling constant $(\mathrm{J}, \mathrm{Hz})$ are in parenthesis.

Table 2. ${ }^{13} \mathrm{C}$ NMR chemical shifts $\left(\delta_{\mathrm{C}}\right.$ in ppm) of compounds 1-4 in $\mathrm{CDCl}_{3}{ }^{\text {a }}$

\begin{tabular}{|c|c|c|c|c|c|c|c|c|}
\hline \multirow[b]{2}{*}{$\mathrm{C}$} & \multicolumn{2}{|r|}{1} & \multicolumn{2}{|c|}{2} & \multicolumn{2}{|r|}{3} & \multicolumn{2}{|r|}{4} \\
\hline & $\delta_{\mathrm{C}}$ & $\mathrm{HMBC}^{\mathrm{a}}$ & $\delta_{\mathrm{C}}$ & $\mathrm{HMBC}^{\mathrm{a}}$ & $\delta_{\mathrm{C}}$ & $\mathrm{HMBC}^{\mathrm{a}}$ & $\delta_{\mathrm{C}}$ & $\mathrm{HMBC}^{\mathrm{a}}$ \\
\hline 2 & 83.1 & $3,2^{\prime}, 6^{\prime}$ & 82.9 & $3,2^{\prime}, 6^{\prime}$ & 83.0 & $3,2^{\prime}$ & 83.5 & $3,2^{\prime}, 6^{\prime}$ \\
\hline 3 & 72.3 & & 72.9 & & 72.9 & 2 & 72.5 & \\
\hline 4 & 195.9 & & 190.8 & 2 & 190.7 & 2 & 196.1 & 2 \\
\hline 5 & 157.7 & & 156.8 & OMe-5 & 156.8 & $4^{\prime \prime}, \mathrm{OMe}-5$ & 159.8 & $\mathrm{OH}-5$ \\
\hline 6 & 103.2 & $8,3^{\prime \prime}, \mathrm{OH}-5$ & 110.8 & $8,3^{\prime \prime}, 4^{\prime \prime}$ & 110.1 & $8,3^{\prime \prime}$ & 110.7 & $8,1^{\prime \prime}$ \\
\hline 7 & $162.3^{\mathrm{b}}$ & 8 & $161.3^{\mathrm{b}}$ & 8 & 161.3 & $8,4^{\prime \prime}$ & 166.5 & OMe-7 \\
\hline 8 & 96.7 & & 101.1 & & 101.1 & & 91.7 & \\
\hline 9 & $162.9^{\mathrm{b}}$ & 8 & $163.7^{\mathrm{b}}$ & 8 & 163.6 & 8 & 161.7 & 8 \\
\hline 10 & 100.4 & $8, \mathrm{OH}-5$ & 106.3 & 8 & 106.3 & 8 & 100.7 & 8, OH-5 \\
\hline $1^{\prime}$ & 129.1 & $2,5^{\prime}$ & 129.5 & $2,3,5^{\prime}$ & 128.7 & $2,3,5^{\prime}$ & 129.5 & $2,3,5^{\prime}$ \\
\hline $2^{\prime}$ & 113.5 & $2,6^{\prime}$ & 113.6 & $2,6^{\prime}$ & 110.2 & $6^{\prime}$ & 113.7 & $2,6^{\prime}$ \\
\hline $3^{\prime}$ & 145.8 & $2^{\prime}, 5^{\prime}$ & 145.8 & $2^{\prime}, 5^{\prime}$ & 149.1 & $5^{\prime}, \mathrm{OMe}-3^{\prime}$ & 146.1 & $2^{\prime}, 5^{\prime}$ \\
\hline $4^{\prime}$ & 147.3 & $2^{\prime}, 5^{\prime}, 6^{\prime}, \mathrm{OMe}-4^{\prime}$ & 147.2 & $2^{\prime}, 6^{\prime}$ & 149.7 & $2^{\prime}, 6^{\prime}, \mathrm{OMe}-4^{\prime}$ & 147.6 & $2^{\prime}, 6^{\prime}, \mathrm{OMe}-4^{\prime}$ \\
\hline $5^{\prime}$ & 110.5 & & 110.5 & & 111.0 & & 110.8 & \\
\hline $6^{\prime}$ & 119.7 & $2,2^{\prime}$ & 119.7 & 2 & 120.3 & $2,2^{\prime}$ & 119.9 & $2,2^{\prime}$ \\
\hline $1^{\prime \prime}$ & & & & & & & 21.2 & \\
\hline $2^{\prime \prime}$ & 78.6 & $3^{\prime \prime}, 4^{\prime \prime}, 2 \mathrm{Me}-2^{\prime \prime}$ & 78.1 & $3^{\prime \prime}$ & 78.1 & $3^{\prime \prime}, 4^{\prime \prime}, 2 \mathrm{Me}-2^{\prime \prime}$ & 122.2 & $1^{\prime \prime}, 4^{\prime \prime}$ \\
\hline $3^{\prime \prime}$ & 126.6 & $2 \mathrm{Me}-2^{\prime \prime}$ & 129.0 & & 129.0 & $2 \mathrm{Me}-2^{\prime \prime}$ & 132.1 & $1^{\prime \prime}, 4^{\prime \prime}, 5^{\prime \prime}$ \\
\hline $4^{\prime \prime}$ & 114.9 & & 115.6 & & 115.6 & & 26.1 & $5^{\prime \prime}$ \\
\hline $5^{\prime \prime}$ & & & & & & & 17.9 & $4^{\prime \prime}$ \\
\hline $2 \mathrm{Me}-2^{\prime \prime}$ & 28.4 & Me-2" & 28.4 & & 28.3 & Me-2" & & \\
\hline OMe-5 & & & 62.6 & & 62.6 & & & \\
\hline OMe-7 & & & & & & & 56.3 & \\
\hline OMe-3' & & & & & 55.8 & & & \\
\hline $\mathrm{OMe}-4^{\prime}$ & 55.9 & & 55.9 & & 55.9 & & 56.2 & \\
\hline
\end{tabular}

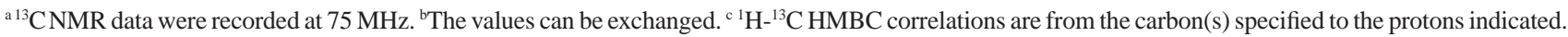




\section{Free-radical (DPPH) scavenging activity}

The radical scavenging activity of compounds 1-4 was evaluated towards the stable free radical DPPH, which exhibits an absorption maximum at $517 \mathrm{~nm}$, evidencing poor activities for compounds 1-4 compared with the positive control trans-resveratrol (Figure 2). Urucuol A (1) showed an $\mathrm{EC}_{50}$ of $124.09 \mu \mathrm{g} \mathrm{mL}^{-1}$, followed by isotirumalin (4) $\left(\mathrm{EC}_{50} 142.31 \mu \mathrm{g} \mathrm{mL}^{-1}\right)$, urucuol B (2) $\left(\mathrm{EC}_{50}\right.$ $\left.154.62 \mu \mathrm{g} \mathrm{mL}^{-1}\right)$ and urucuol C (3) $\left(\mathrm{EC}_{50} 405.86 \mu \mathrm{g} \mathrm{mL}^{-1}\right)$. These results showed that compounds 1-4 were 7-23 times less active than positive control trans-resveratrol $\left(\mathrm{EC}_{50}\right.$ value of $17.69 \mu \mathrm{g} \mathrm{mL}^{-1}$ ).

The free radical scavenging activity of flavonoids and other phenols is mostly due to their aromatic hydroxyl groups, which afford greater stability to the phenolic radical as soon as it is formed, after one hydrogen radical donation to DPPH, ${ }^{36}$ so the dihydroxylated dihydroflavanols $\mathbf{1}$ and $\mathbf{4}$ were more effective in promoting DPPH reduction, compared with the monohydroxylated $\mathbf{2}$ and the unhydroxylated $\mathbf{3}$, the least active.

Dihydroflavonols show a different behavior compared with flavones or flavonols. The methylation in the hydroxyl group at the para-position decreased DPPH scavenging activity. Other studies show that a $\mathrm{C}_{2}-\mathrm{C}_{3}$ double bond and the catechol absence decrease scavenging activity. ${ }^{37-39}$ An additional methylation in the meta-position significantly decreased DPPH scavenging capacity. Based on all the information cited, it is possible to justify the lesser antioxidant activity of the compounds tested compared to the resveratrol, whose structure presents trihydroxylation at the para- and meta-positions and an all conjugated system.

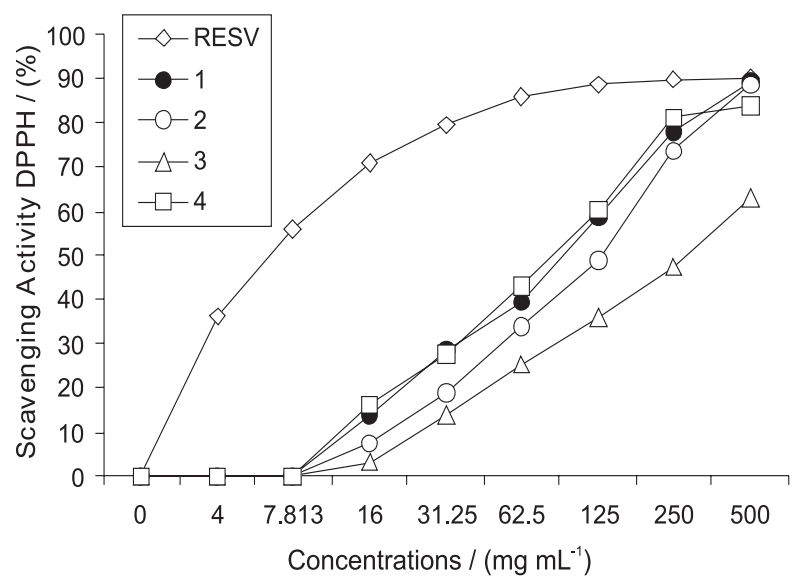

Figure 2. Dose-response curve for radical scavenging activity of the dihydroflavonols 1-4 isolated from leaves of the Derris urucu by DPPH method at different concentrations. trans-resveratrol (RESV) was used as reference compound.

\section{Experimental}

\section{General}

IR spectra were obtained in a Bomen MB-102 spectrophotometer, using the thin solid film method. UV spectra were obtained from a Shimadzu Prominence 20A LC equipped with DAD. NMR spectra, including ${ }^{1} \mathrm{H}-{ }^{1} \mathrm{H}$ COSY, HETCOR, HMBC experiments, were recorded on a Varian Mercury-300 spectrometer, operating at $300 \mathrm{MHz}$ for ${ }^{1} \mathrm{H}$ and $75 \mathrm{MHz}$ for ${ }^{13} \mathrm{C}$, using d-chloroform as solvent and internal standard. Mass spectral analyses were performed at low resolution on a Quattro-LC instrument (Micromass, Manchester, UK) provided with an ESI ion source and a triple quadrupole mass analyzer. High resolution analyses were performed on UltrOTOF-Q (Brucker, Daltonics, Billerica MA, USA) only in the cationized ion region. After a systematic investigation, the heated capillary and the voltage were maintained at $250{ }^{\circ} \mathrm{C}$ and $3 \mathrm{kV}$, respectively. A $20 \mathrm{~V}$ (cone energy) was applied for the ion extraction and the mass spectrometry data were acquired in the positive mode for all compounds. HPLC was carried out in a preparative LC-8A Shimadzu system with SPD-10AV Shimadzu UV detector (Tokyo, Japan); using a Phenomenex Gemini C18 column $(250 \mathrm{~mm} \times 10 \mathrm{~mm}, 5 \mu \mathrm{m})$, an isocratic system of water/acetonitrile (46:54) and a flow rate of $4.7 \mathrm{~mL}$ per min. Detection was performed at 270 and $320 \mathrm{~nm}$. All solvents were filtered through a $0.45 \mu \mathrm{m}$ membrane filter prior to use. Absorbance measurements were recorded on a Spectrum UV SP-220 spectrophotometer.

\section{Plant material}

The leaves of Derris urucu were collected in January 2006, in the forest reserve of EMBRAPA-Amazônia Oriental in Belém, Pará State, Brazil. A voucher specimen (IAN 179599) was deposited at the herbarium of this institution.

\section{Extraction and isolation}

The dried and powdered leaves of Derris игиси (300 g) were extracted with ethanol at room temperature. The solvent was removed under vacuum furnishing a residue $(50 \mathrm{~g})$. The crude ethanol residue ( $30 \mathrm{~g}$ ) was passed through a silica gel column with gradient elution: hexane-ethyl acetate $(9: 1,7: 3$, 5:5 and 0:10) and ethyl acetate-methanol (5:5 and 0:10), yielding, after removal of the organic solvent, six fractions named DU-1 (1.28 g), DU-2 (2.37 g), DU-3 (5.17 g), DU-4 (5.36 g), DU-5 (3.53 g) and DU-6(3.75 g), respectively. The ${ }^{1} \mathrm{HNMR}$ and HPLC analysis of these fractions showed that 
the DU-4 was the most interesting as it had aromatic proton signals and a chromatogram with intense peaks, suggesting the presence of the aromatic compounds. Fraction DU-4 $(1 \mathrm{~g})$ was purified by semi-preparative HPLC yielding four dihydroflavonols: $\mathbf{1}(20 \mathrm{mg}), \mathbf{2}(28 \mathrm{mg}), \mathbf{3}(80 \mathrm{mg})$ and $4(20 \mathrm{mg})$, which showed peaks in the chromatogram with retention times of 9.10, 7.84, 13.52 and $16.28 \mathrm{~min}$, respectively.

\section{DPPH assays}

A methanolic solution $\left(25 \mathrm{mg} \mathrm{L}^{-1}\right)$ of the radical DPPH was prepared daily and protected from light. Absorbance was recorded to check the stability of the radical throughout the time of analysis. The effect of phenolic compounds on the $\mathrm{DPPH}^{*}$ absorbance was estimated by using the procedure described in the literature. ${ }^{20}$ Different sample concentrations dissolved in methanol were added to DPPH ${ }^{\circ}$ methanolic solutions. Absorbance at $517 \mathrm{~nm}$ was recorded at different time intervals until the reaction reached an equilibrium. The initial absorbance was close to $1.100-$ 1.150 in all cases. The blank reference cuvette contained methanol. All measurements were performed in duplicate. Six different concentrations of each phenolic compound studied were assayed in order to check the linearity of response and to establish the antioxidant activity values in an adequate linear range. All phenolic compounds were properly dissolved in methanol.

\section{Data analysis}

Reaction kinetics of phenols with DPPH were registered for each antioxidant concentration tested. From these plots, the percentage of DPPH' remaining at the steady state $\left(\mathrm{DPPH}^{*}\right.$ rem $)$ was determined as $\% \mathrm{DPPH}^{\bullet}$ rem $=$ $\left(A_{\mathrm{f}} / A_{0}\right) \times 100 . A_{0}$ and $A_{\mathrm{f}}$ correspond to the absorbances at $517 \mathrm{~nm}$ of the radical at the beginning and at the steady state, respectively. Time at steady state was used in order to ensure that reaction did not progress further. Concentrations of the phenolic compounds in the reaction medium were plotted against the percentages of the remaining DPPH ${ }^{\cdot}$ at the end of the reaction in order to obtain the $\mathrm{EC}_{50}$ index, defined as the amount of antioxidant needed to decrease the initial $\mathrm{DPPH}^{*}$ concentration by $50 \%$. Analysis of variance and linear correlations tests were performed using the BIOSTAT ${ }^{\circledR}$ version software package.

\section{Urucuol A (1)}

Pale yellow powder; IR (thin solid film) $v_{\max } / \mathrm{cm}^{-1}$ : 3345, 2974, 1633, 1514, 1434, 1282, 1129, 1016. UV (water:acetonitrile) $\lambda_{\max } / \mathrm{nm}: 229,272,309(s h)$;
ESI-MS m/z: 407, $385[\mathrm{M}+\mathrm{H}]^{+}, 325\left[\mathrm{M}+\mathrm{Na}-58\left(\mathrm{C}_{3} \mathrm{H}_{6} \mathrm{O}\right)-\mathrm{H}\right]^{+}$, $284\left[\mathrm{M}+\mathrm{H}-58\left(\mathrm{C}_{3} \mathrm{H}_{6} \mathrm{O}\right)-28-15\right]^{+}, 236 ;{ }^{1} \mathrm{H}$ and ${ }^{13} \mathrm{C}$ NMR spectral data: see Tables 1 and 2 .

\section{Urucuol B (2)}

Yellow amorphous powder; IR (thin solid film) $v_{\max } / \mathrm{cm}^{-1}$ : 3397, 2933, 1597, 1511, 1445, 1266, 1127, 1028. UV (water:acetonitrile) $\lambda_{\max } / \mathrm{nm}: 235,261,342(s h)$; ESI-MS $m / z: 421[\mathrm{M}+\mathrm{Na}]^{+}, 399[\mathrm{M}+\mathrm{H}]^{+}, 325\left[\mathrm{M}+\mathrm{Na}-58\left(\mathrm{C}_{3} \mathrm{H}_{6} \mathrm{O}\right)-\right.$ $\left.15\left(\mathrm{CH}_{3}\right)\right]^{+}, 284\left[\mathrm{M}+\mathrm{H}-58\left(\mathrm{C}_{3} \mathrm{H}_{6} \mathrm{O}\right)-28(\mathrm{CO})-28(\mathrm{CO})-\mathrm{H}\right]^{+}$, 236; ${ }^{1} \mathrm{H}$ and ${ }^{13} \mathrm{C}$ NMR spectral data: see Tables 1 and 2.

\section{Urucuol C (3)}

Yellow amorphous powder; IR (thin solid film) $v_{\max } / \mathrm{cm}^{-1}$ : 3418, 2934, 1606, 1529, 1467, 1261, 1129, 1082, 1022; UV (water/acetonitrile) $\lambda_{\max } / \mathrm{nm}: 235,261,342(s h)$; ESI-MS $m / z: 435[\mathrm{M}+\mathrm{Na}]^{+}, 413[\mathrm{M}+\mathrm{H}]^{+}, 325\left[\mathrm{M}+\mathrm{Na}-58\left(\mathrm{C}_{3} \mathrm{H}_{6} \mathrm{O}\right)-\right.$ $28(\mathrm{CO})-\mathrm{H}]^{+}, 284\left[\mathrm{M}+\mathrm{H}-58\left(\mathrm{C}_{3} \mathrm{H}_{6} \mathrm{O}\right)-28(\mathrm{CO})-15\left(\mathrm{CH}_{3}\right)-\right.$ 28(CO) $]^{+}, 236 ;{ }^{1} \mathrm{H}$ and ${ }^{13} \mathrm{C}$ NMR spectral data: see Tables 1 and 2.

\section{Isotirumalin (4)}

White amorphous powder; IR (thin solid film) $v_{\max } / \mathrm{cm}^{-1}$ : 3458, 3206, 2934, 1632, 1574, 1434, 1248, 1129, 1095, 1016; UV (water/acetonitrile) $\lambda_{\max }$ /nm: 233, 291, 335 $(s h)$; ESI-MS m/z: $423[\mathrm{M}+\mathrm{Na}]^{+}, 401[\mathrm{M}+\mathrm{H}]^{+}, 345[\mathrm{M}+\mathrm{H}-$ $\left.55\left(\mathrm{C}_{4} \mathrm{H}_{7}\right)\right]^{+}, 325\left[\mathrm{M}+\mathrm{H}-32\left(\mathrm{CH}_{3} \mathrm{OH}\right)-42\left(\mathrm{C}_{3} \mathrm{H}_{6}\right)-\mathrm{H}\right]^{+}, 284$ $\left[\mathrm{M}+\mathrm{H}-32\left(\mathrm{CH}_{3} \mathrm{OH}\right)-42\left(\mathrm{C}_{3} \mathrm{H}_{6}\right)-28(\mathrm{CO})-15\left(\mathrm{CH}_{3}\right)\right]^{+}, 236 ;{ }^{1} \mathrm{H}$ and ${ }^{13} \mathrm{C}$ NMR spectral data: see Tables 1 and 2.

\section{Acknowledgments}

The authors are grateful to the Conselho Nacional de Desenvolvimento Científico e Tecnológico (CNPq) for financial support and to the Coordenação de Aperfeiçoamento de Pessoal de Nível Superior (CAPES) for scholarships. We are also thankful to Dr. Norberto P. Lopes of Faculdade de Farmácia-USP-Ribeirão Preto for the ESI-MS and HRESI-MS.

\section{Supplementary Information}

Supplementary data is available free of charge at http://jbcs.sbq.org.br, as a PDF file.

\section{References}

1. Conceição, H. E. O.; Pinto, J. E. B. P.; Santiago, E. J. A.; Gonçalves, A. A. S.; Cienc. Agrotec. 2002, 26, 472.

2. Da Costa, J. P.; Alves, S. M.; Belo, M.; Acta Amaz. 1999, 29 , 563. 
3. Gusmão, S. D.; Páscoa, V.; Mathias, L.; Vieira, I. J. C.; BrazFilho, R.; Lemos, F. J. A.; Mem. Inst. Oswaldo Cruz 2002, 97, 371.

4. Mors, W. B.; Do Nascimento, M. C.; Ribeiro do Valle, J.; Aragão, J. A.; Cienc. Cult. 1973, 25, 647.

5. Fang, N.; Casida, J. E.; J. Agric. Food Chem. 1999, 47, 2130.

6. Fang, N.; Casida, J. E.; J. Nat. Prod. 1999, 62, 205.

7. Russo, A.; Acquaviva, R.; Campisi, A.; Sorrentini, V.; Di Giacomo, C.; Cell Biol. Toxicol. 2000, 63, 1035.

8. Hirono, I.; Biol. Pharm. Bull. 1987, 2, 120.

9. Alldrick, A.; Flynn, J.; Rowland, I.; Mutat. Res. 1986, 163, 225.

10. Kawaii, S.; Tomono, Y.; Katase, E.; Ogawa, K.; Yano, M.; Biosci. Biotechnol. Biochem. 1999, 63, 896.

11. Sakihama, Y.; Cohen, M.; Grace, S.; Yamasaki, H.; Toxicology 2002, 177, 67.

12. Vaya, J.; Mahmood, S.; Goldblum, A.; Aviram, M.; Volkova, N.; Salan, A.; Musa, M.; Tamir, S.; Phytochemistry 2003, 62, 89.

13. Pietta, P.; J. Nat. Prod. 2000, 63, 1035.

14. Morel, I.; Lescoat, G.; Cogrel, P.; Sergent, O.; Pasdeloup, N.; Brissot, P.; Cillard, P.; Biochem. Pharmacol. 1993, 45, 13.

15. Teguo, P. W.; Fauconneau, B.; Deffieux, G.; Huguet, F.; Vercauteren, J.; Mérillon, J. M.; J. Nat. Prod. 1998, 61, 655.

16. Escobar, C. L. M.; Braga, A.; Tommasi, N. D.; J. Nat. Prod. 2003, 66, 1061.

17. Nakamura, Y.; Watanabe, S.; Miyake, N.; Kohno, H.; Osawa, T.; J. Agric. Food Chem. 2003, 51, 3309.

18. Robards, K.; Prenzlere, P. D.; Tucker, G.; Swatsitang, P.; Glover, W.; Food Chem. 1999, 66, 401.

19. Galati, G.; Sabzevari, O.; Wilson, J. X.; O’Brien, P. J.; Toxicology 2002, 177, 91.

20. Brand-Williams, W.; Cuvelier, M. E.; Berset, C.; Food Sci. Technol. 1995, 28, 25.

21. Arnous, A.; Makris, D. P.; Kefalas, P.; J. Agric. Food Chem. 2001, 49, 5736.

22. Da Porto, C.; Calligaris, S.; Celotti, E.; Nicoli, M. C.; J. Agric. Food Chem, 2000, 48, 4241.

23. Gorinstein, S.; Martin-Belloso, O.; Katrich, E.; Lojak, A.; Ciz, M.; Gligelmo-Miguel, N.; Haruenkit, R.; Park, Y.-S.; Jung, S.T.; Trakhtenberg, S.; J. Nutr. Biochem. 2003, 14, 154.
24. Heinonen, I. M.; Lehtonen, P. J.; Hopia, A. I.; J. Agric. Food Chem. 1998, 46, 25.

25. Llorach, R.; Espín, J. C.; Tom`as-Barberán, F.A.; Ferreres, F.; J. Agric. Food Chem. 2003, 51, 2181.

26. Sánchez-Moreno, C.; Plaza, L.; De Ancos, B.; Cano, M. P.; J. Sci. Food Agric. 2003, 83, 430.

27. Gil, M. I.; Tom'as-Barber'an, F. A.; Hess-Pierce, B.; Holcroft, D. M.; Kader, A. A.; J. Agric. Food Chem. 2000, 48, 4581.

28. Lu, Y.; Foo, L.Y.; Food Chem. 2000, 68, 81.

29. Goupy, P.; Dufour, C.; Loonis, M., Dangles, O.; J. Agric. Food Chem. 2003, 51, 615.

30. Mabry, T.; Markham, K. R.; Thomas, M. B.; The Systematic Identification of flavonoids, Springer-Verlag: New York, 1970, p. 166.

31. Mbwambo, Z. H.; Kapingu, M. C.; Moshi, M. J.; Machumi, F.; Apers, S; Cors, P.; Ferreira, D.; Marais, J. P. J.; Vanden Berghe, D.; Maes, L.; Vlietinck, A.; Pieters, L.; J. Nat. Prod. 2006, 69, 369.

32. Rao, K. V.; Gunasekar, D.; Phytochemistry 1998, 48, 1453.

33. Nkengfack, A. E.; Kouam, J.; Voufoo, W. T.; Fomum, Z. T.; Dagne, E.; Sterner, O.; Browne, L. M.; Guijun, J.; Phytochemistry 1993, 32, 1305.

34. Agrawal, P. K.; Rastogi, R. P.; Heterocycles 1981, 16, 2181.

35. Rao, K. V; Gunasekar, D.; Indian J. Chem., Sect. B: Org. Chem. Incl. Med. Chem. 1988, 27, 383.

36. Ribeiro, A. B.; Bolzani, V. S., Yoshida, M.; Santos, L. S.; Eberlin, M. N.; Silva, D. H. S.; J. Braz. Chem. Soc. 2005, 16, 526.

37. Trouillas, P.; Marsal, P; Siri, D.; Lazzaroni, R.; Duroux, J.-L.; Food Chem. 2006, 97, 679.

38. Van Acker, S. A. B. E.; Van Den Berg, D.-J.; Tromp, M. N. J. L.; Griffioen, D. H.; Van Bennekom, W. P.; Van Der Vijgh, W. J. F.; Bast. A.; Free Radical Biol. Med.1996, 20, 331.

39. Leopoldini, M.; Russo, N.; Toscano, M.; J. Agric. Food Chem. 2006, 54, 3078.

Received: January 29, 2009

Web Release Date: June 26, 2009 


\section{Dihydroflavonols from the leaves of Derris urucu (Leguminosae): Structural Elucidation and DPPH Radical-Scavenging Activity}

Livia T. Lôbo, ${ }^{a}$ Geilson A. da Silva, ${ }^{a}$ Malisson Ferreira, ${ }^{a}$ Milton N. da Silva,${ }^{a}$ Alberdan S. Santos, ${ }^{a}$ Alberto C. Arruda, ${ }^{a}$ Giselle M. S. P. Guilhon, ${ }^{a}$ Lourivaldo S. Santos, ${ }^{a}$ Rosivaldo dos Santos Borges ${ }^{b}$ and Mara Silvia P. Arruda*,a

aPrograma de Pós-Graduação em Química, Instituto de Ciências Exatas e Naturais, Universidade Federal do Pará, Campus Universitário do Guamá, 66075-970 Belém-PA, Brazil

${ }^{b}$ Faculdade de Farmácia, Instituto de Ciências da Saúde, Universidade Federal do Pará, Campus Universitário do Guamá, 66075-970 Belém-PA, Brazil

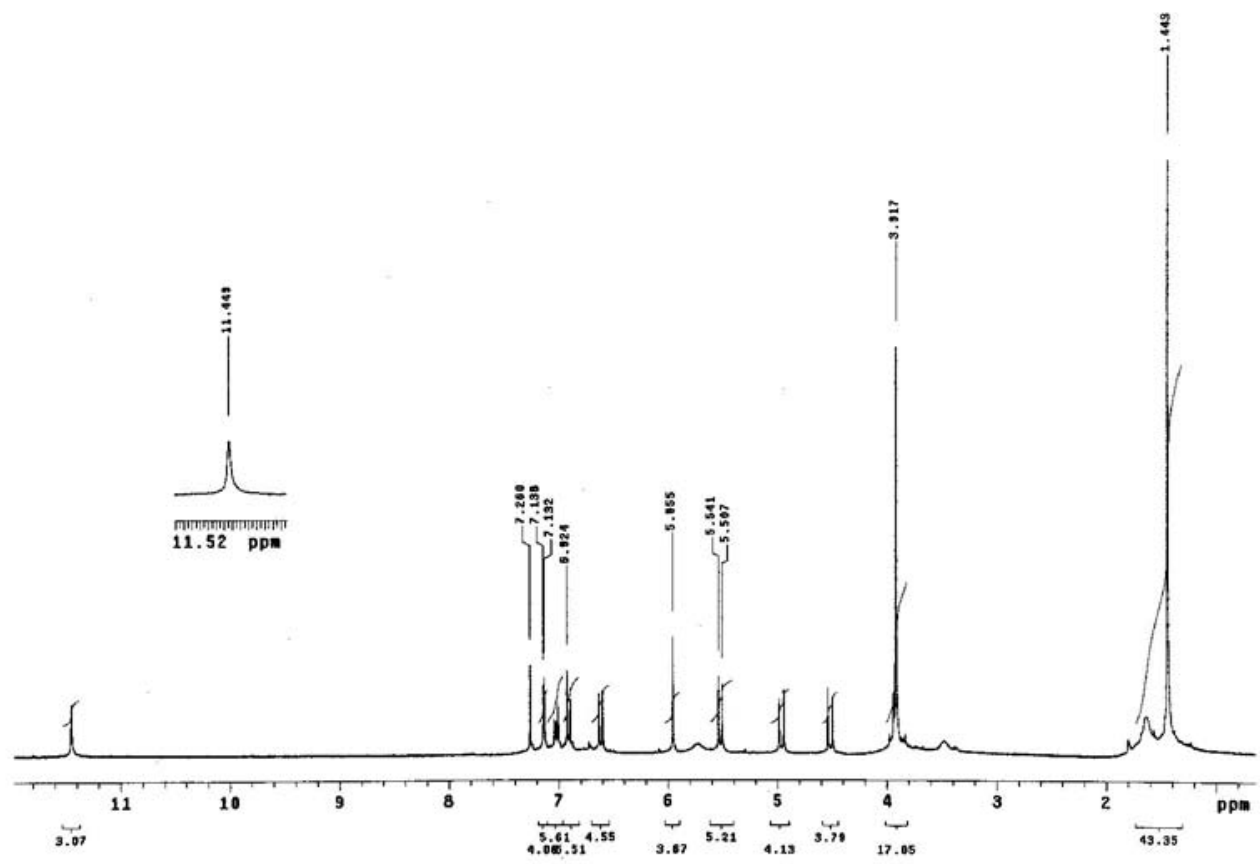

Figure S1. ${ }^{1} \mathrm{H}$ NMR spectrum (in $\mathrm{CDCl}_{3}, 300 \mathrm{MHz}$ ) of the compound 1 isolated from leaves of Derris urucu. 


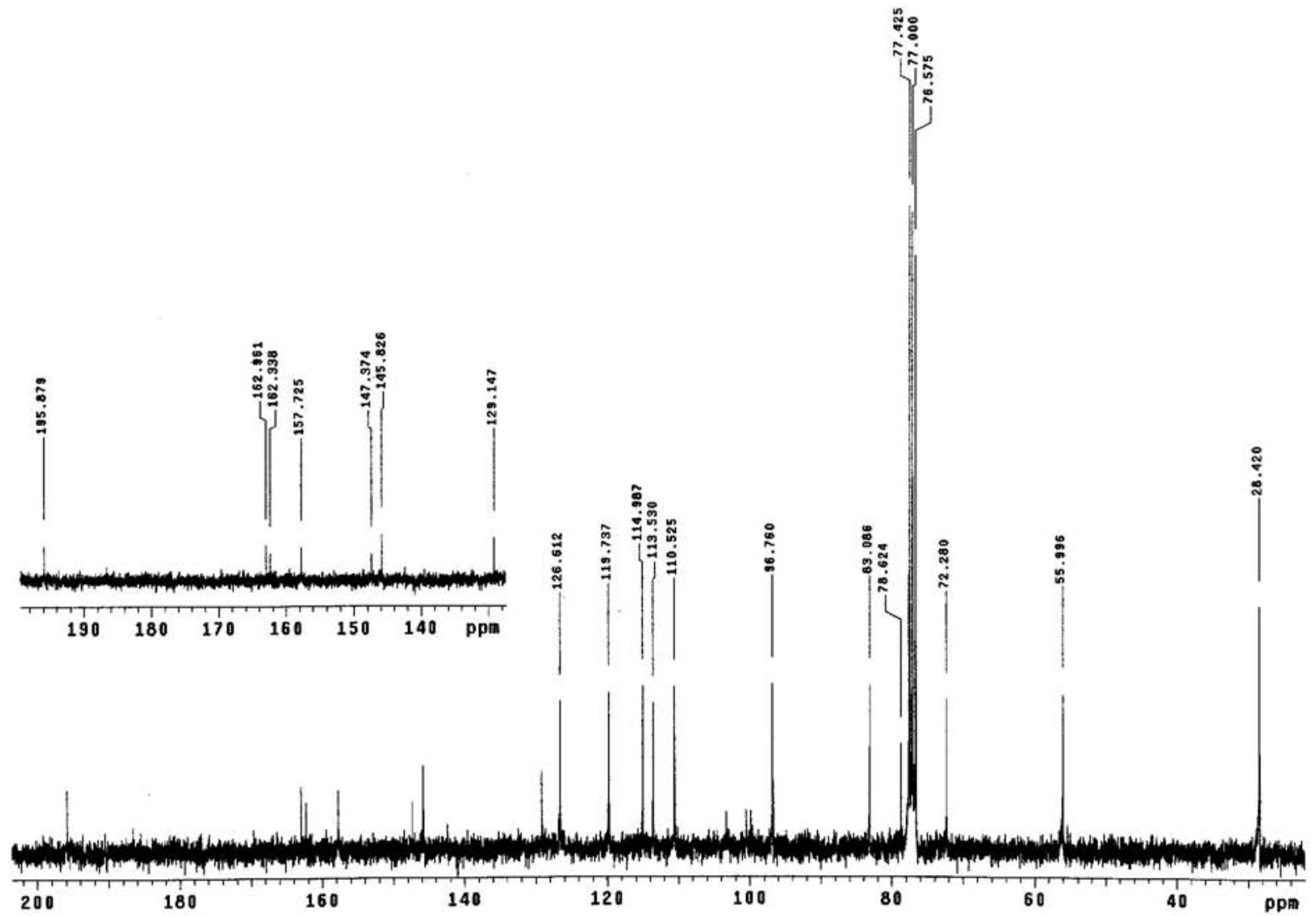

Figure S2. ${ }^{13} \mathrm{C}$ NMR spectrum (in $\mathrm{CDCl}_{3}, 75 \mathrm{MHz}$ ) of the compound $\mathbf{1}$ isolated from leaves of Derris urucu.

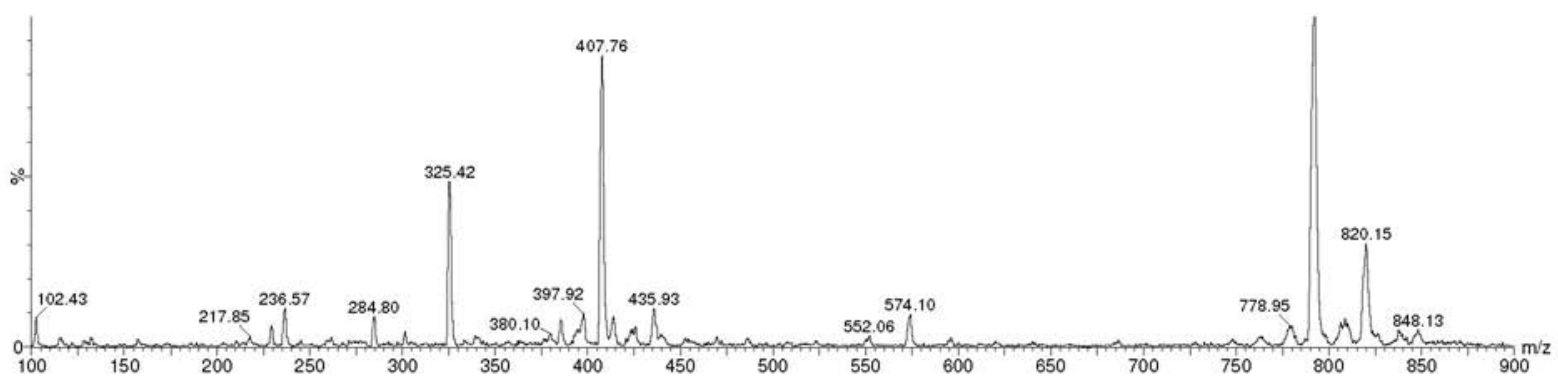

Figure S3. ESI mass spectrum of the compound $\mathbf{1}$ isolated from leaves of Derris urucu. 


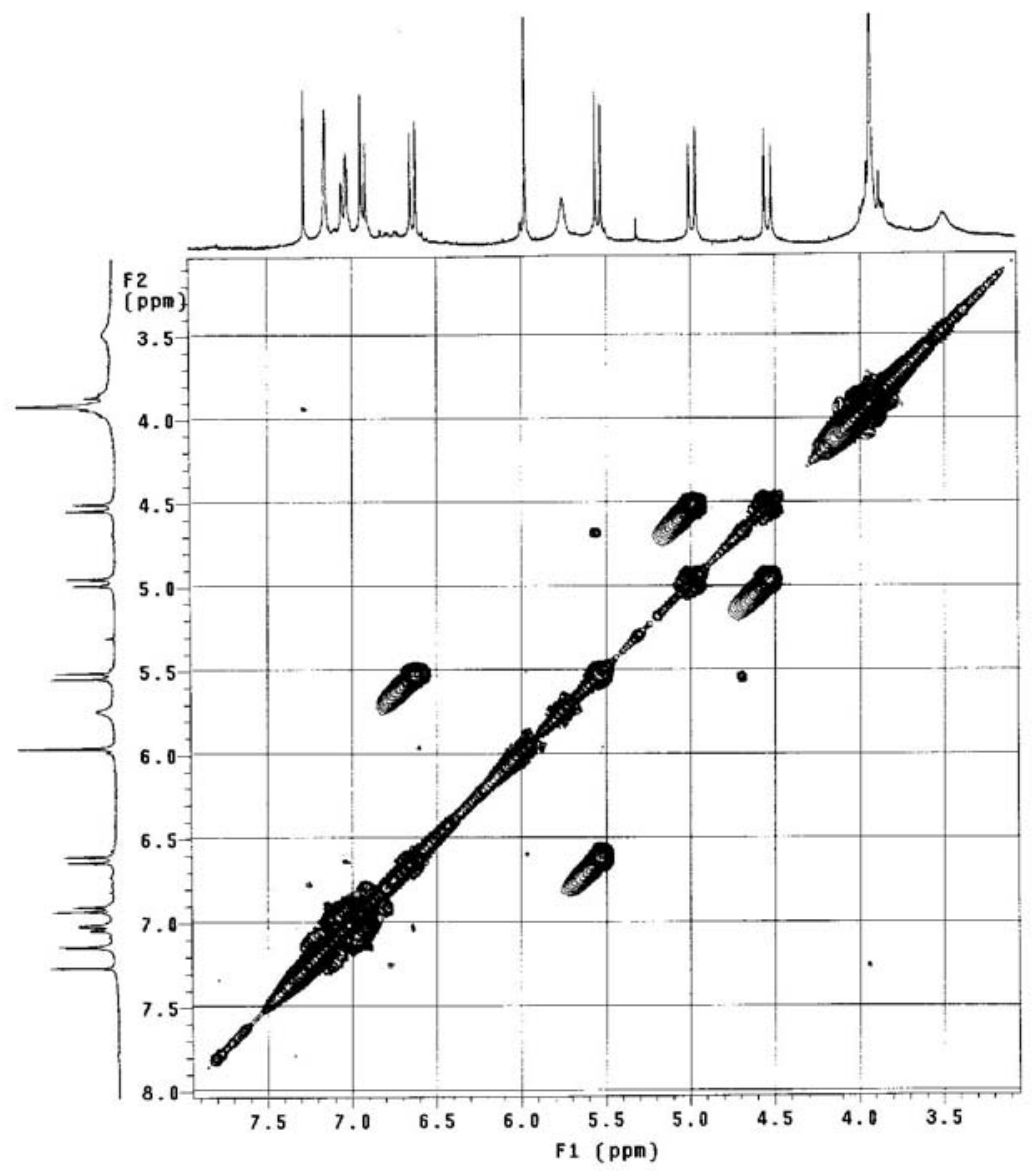

Figure S4. COSY NMR experiment (in $\mathrm{CDCl}_{3}, 300 \mathrm{MHz}$ ) of the compound 1 isolated from leaves of Derris urucu.

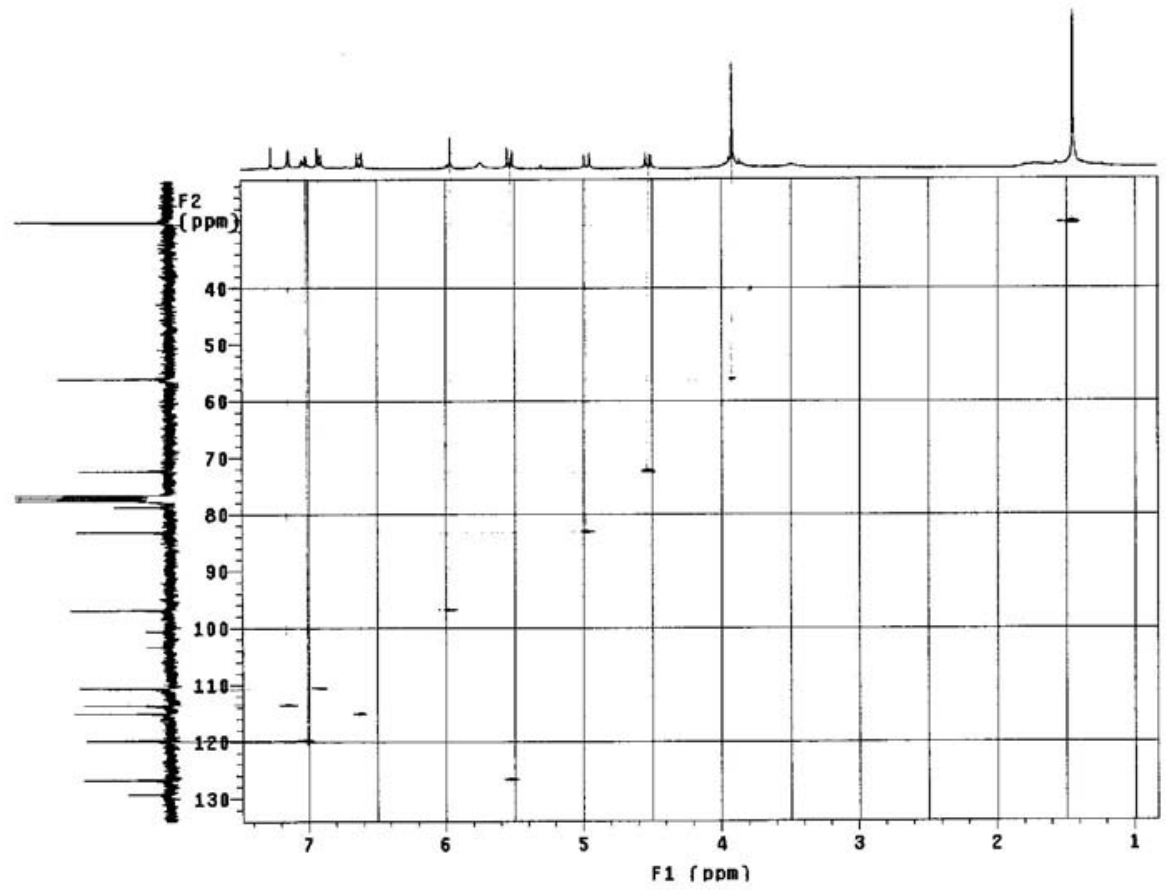

Figure S5. HETCOR NMR experiment (in $\mathrm{CDCl}_{3}, 300 \times 75 \mathrm{MHz}$ ) of the compound 1 isolated from leaves of Derris urucu. 


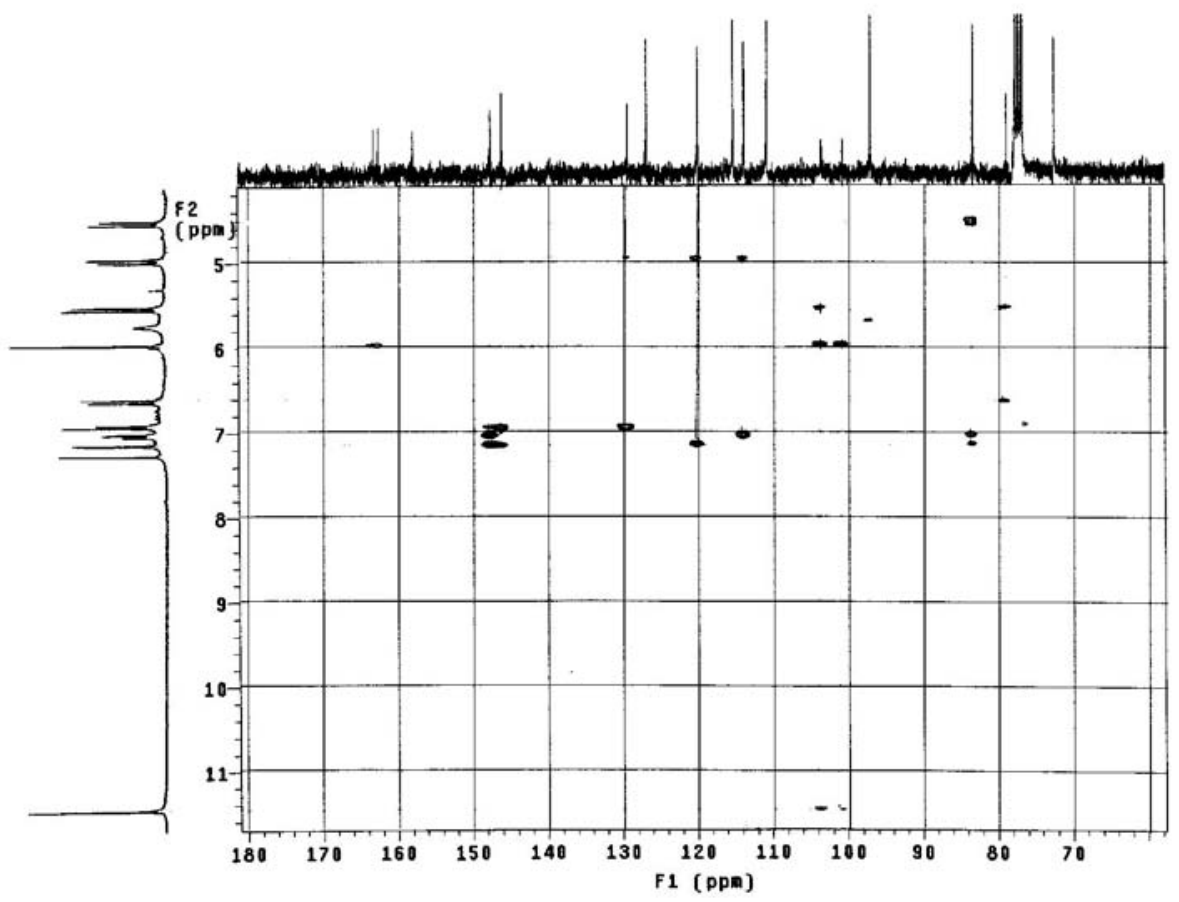

Figure S6. $\mathrm{HMBC}$ NMR experiment (in $\mathrm{CDCl}_{3}, 300 \times 75 \mathrm{MHz}$ ) of the compound 1 isolated from leaves of Derris urucu.

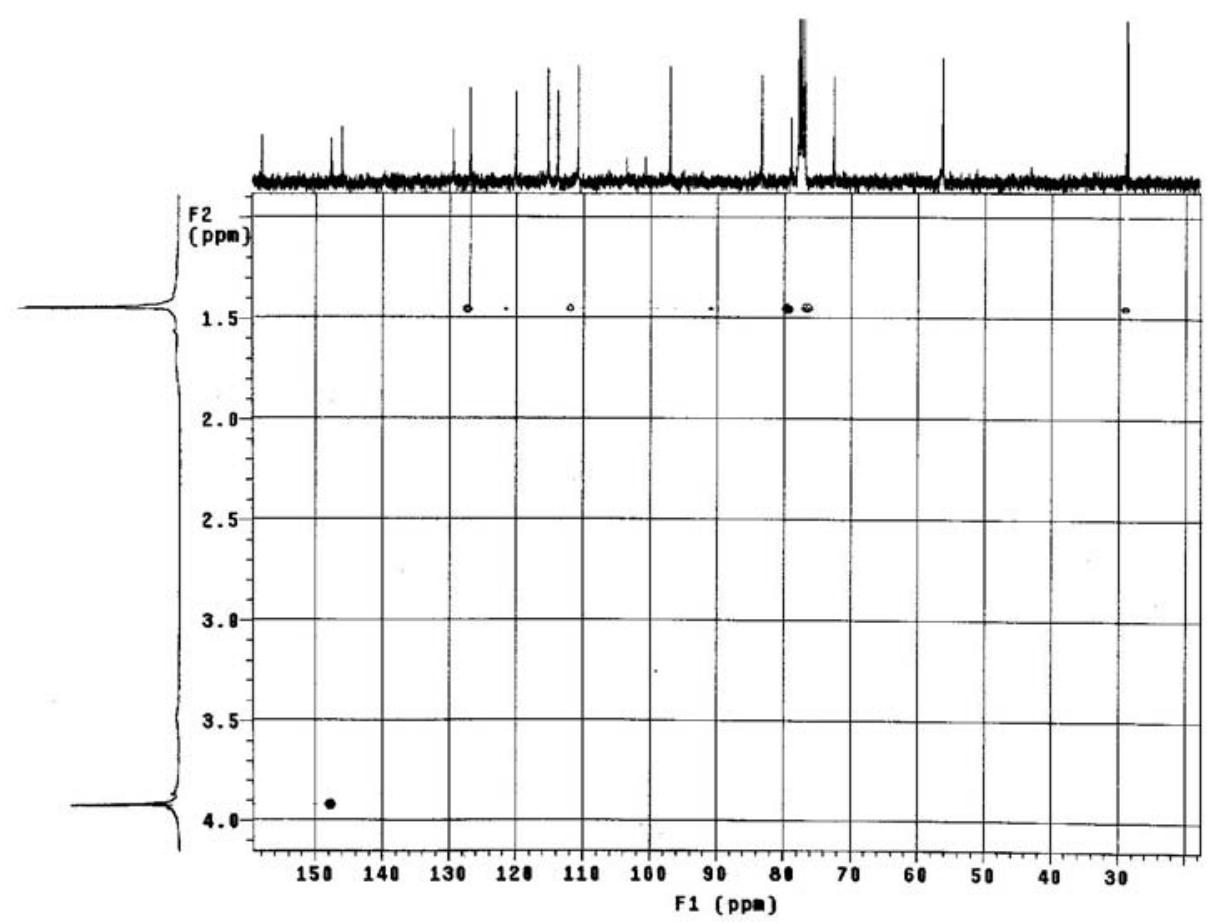

Figure S7. HMBC NMR experiment of the compound 1 (expansion). 


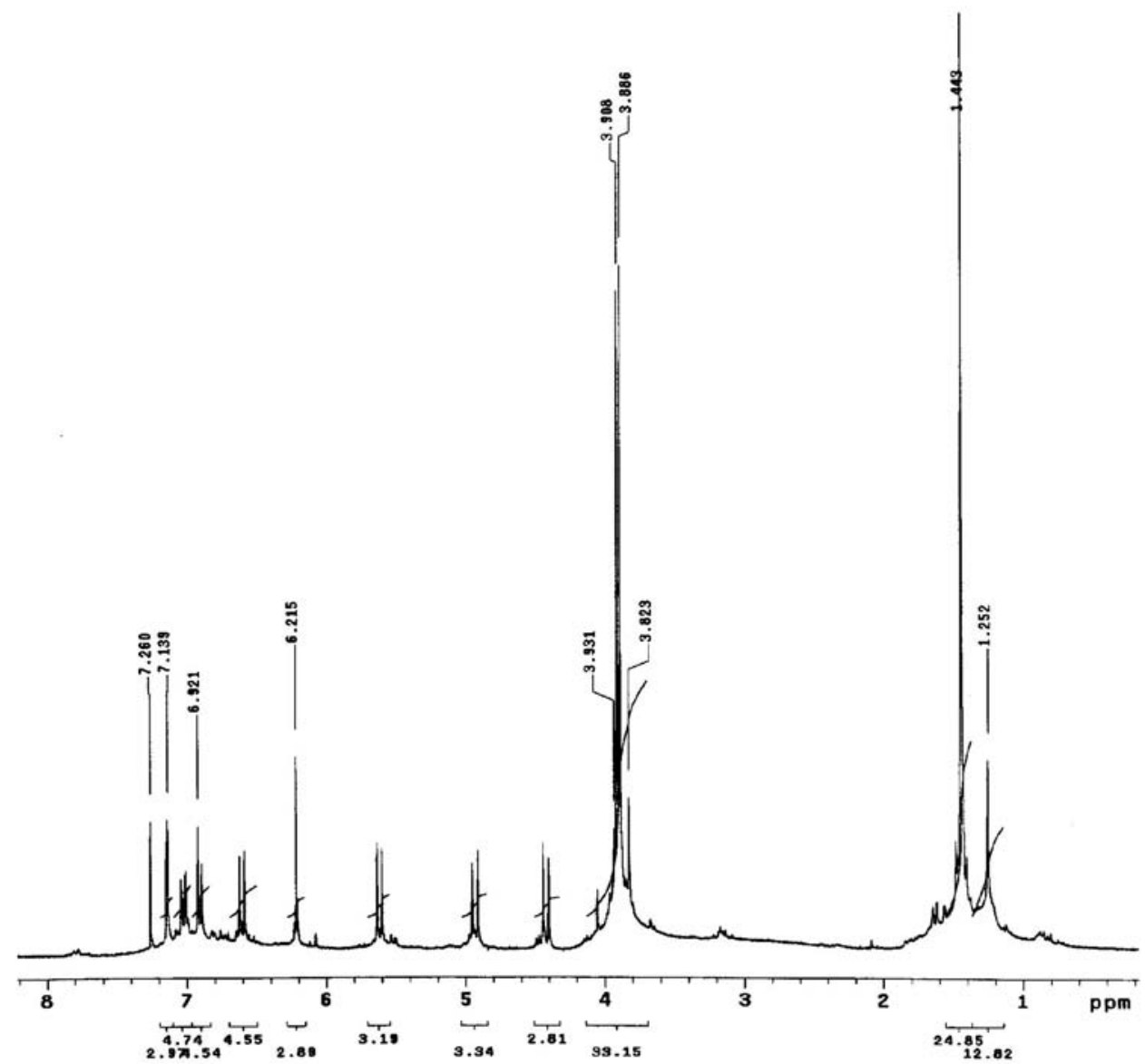

Figure S8. ${ }^{1} \mathrm{H}$ NMR spectrum (in $\mathrm{CDCl}_{3}, 300 \mathrm{MHz}$ ) of the compound 2 isolated from leaves of Derris urucu.

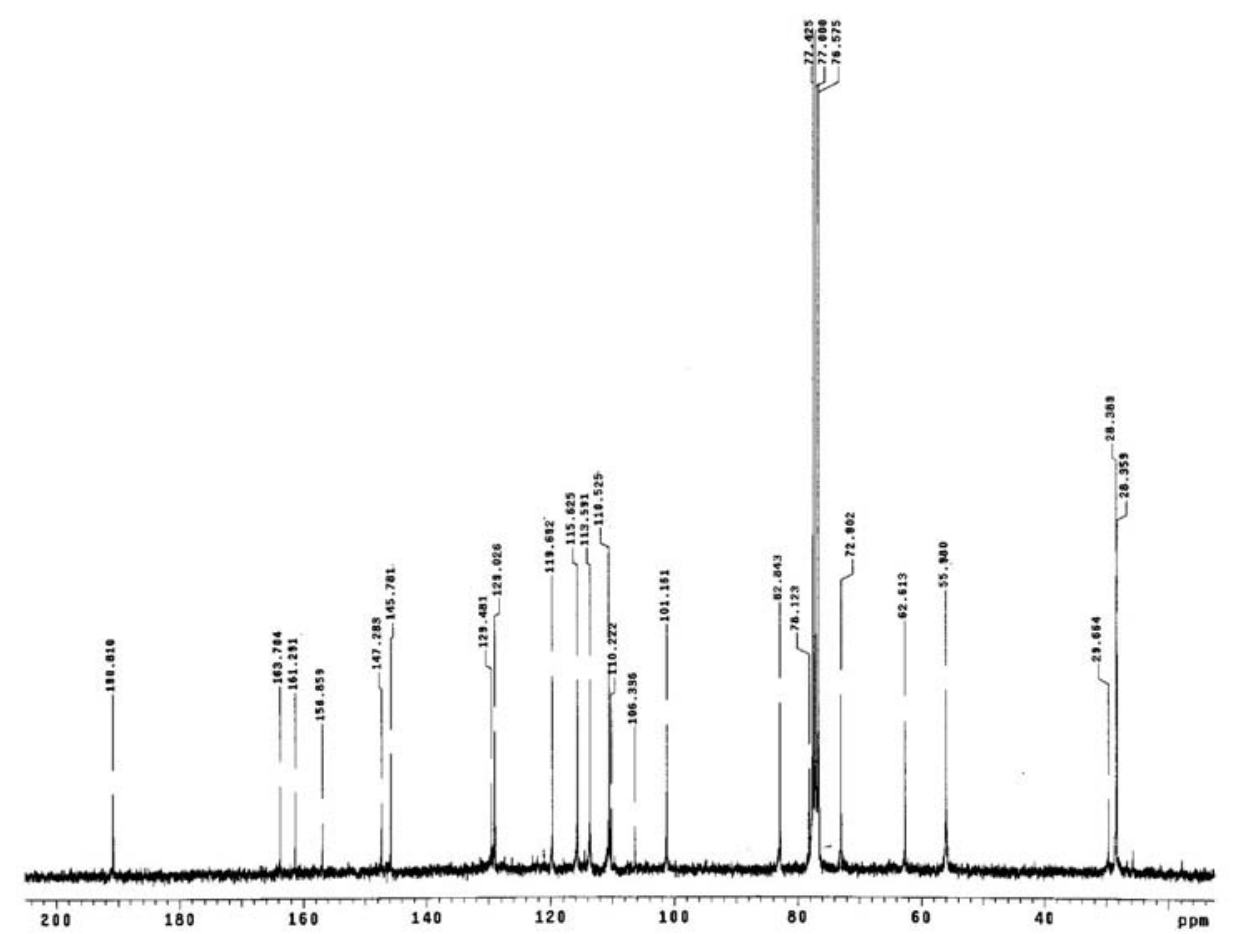

Figure S9. ${ }^{13} \mathrm{C}$ NMR spectrum (in $\mathrm{CDCl}_{3}, 75 \mathrm{MHz}$ ) of the compound 2 isolated from leaves of Derris urucu. 


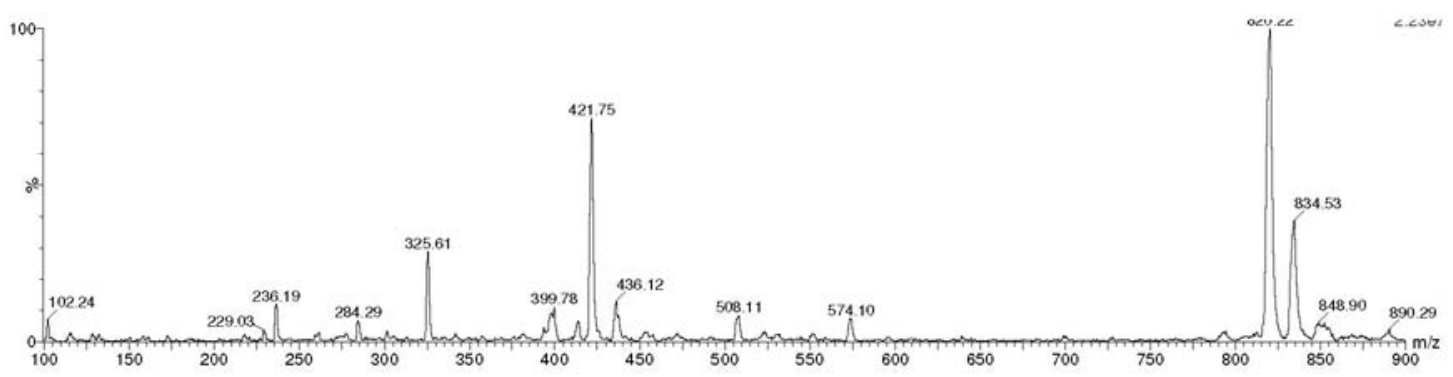

Figure S10. ESI mass spectrum of the compound 2 isolated from leaves of Derris urucu.

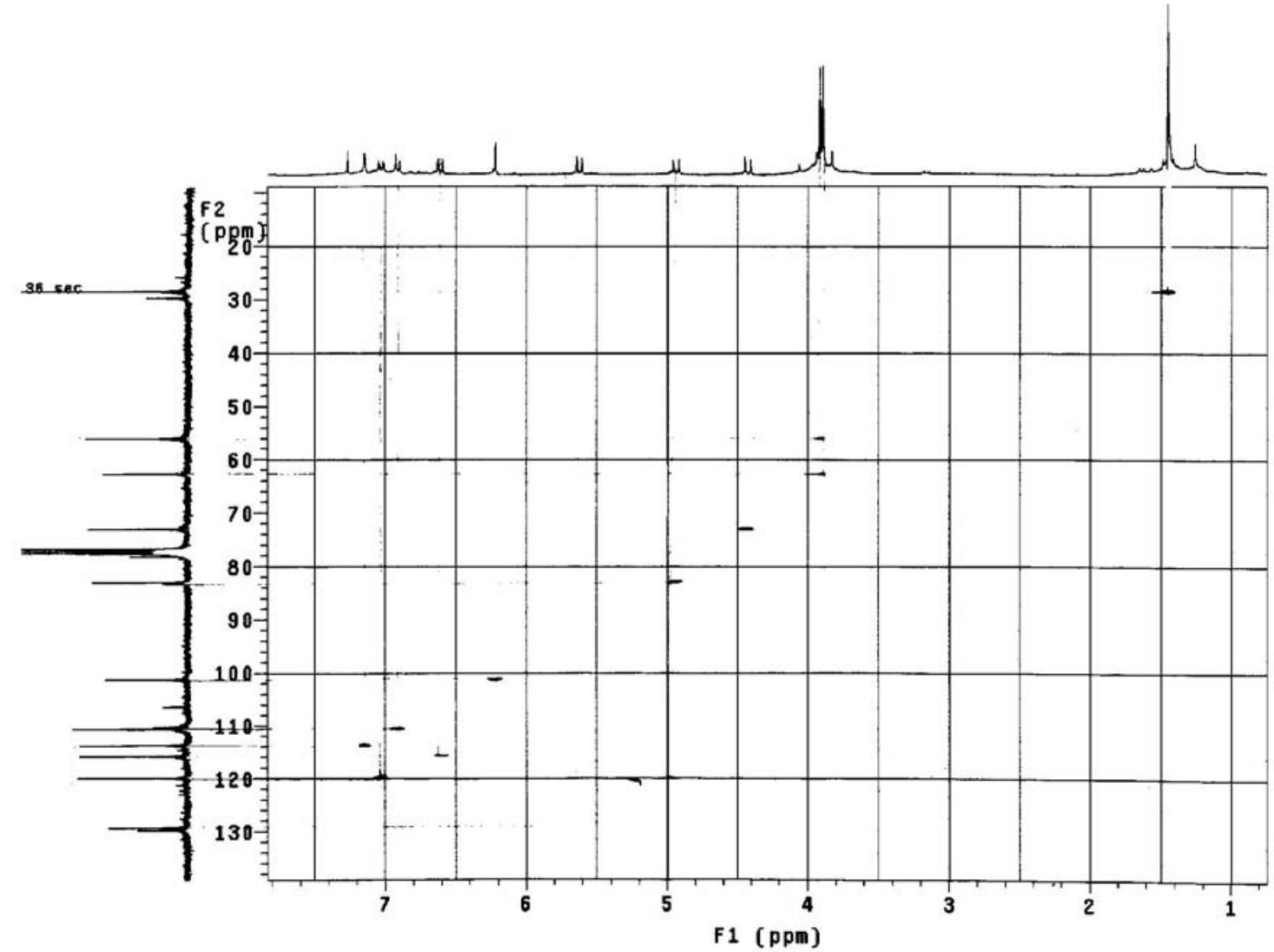

Figure S11. HETCOR NMR experiment (in $\mathrm{CDCl}_{3}, 300 \times 75 \mathrm{MHz}$ ) of the compound 2 isolated from leaves of Derris urucu. 


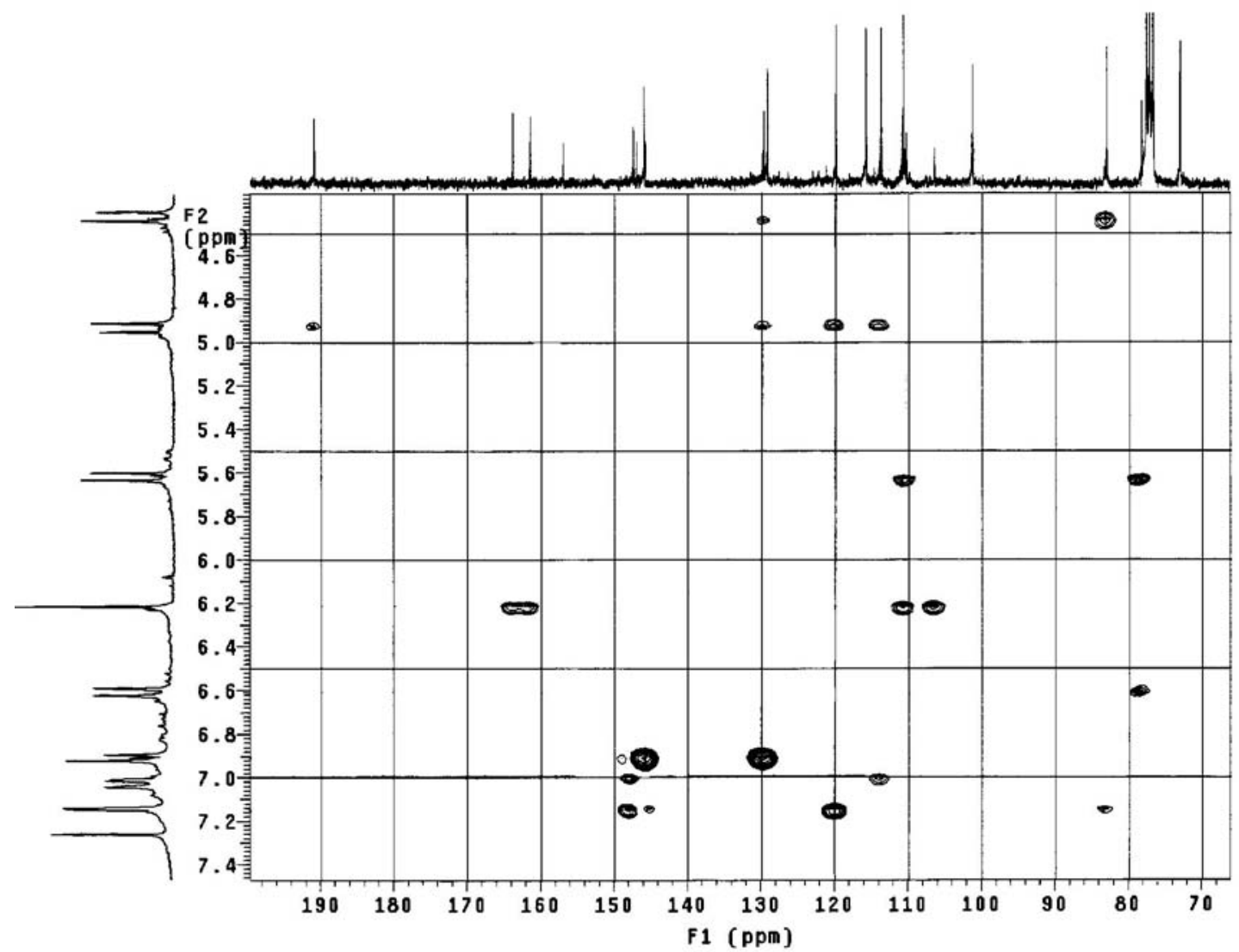

Figure S12. $\mathrm{HMBC}$ NMR experiment (in $\mathrm{CDCl}_{3}, 300$ x $75 \mathrm{MHz}$ ) of the compound 2 isolated from leaves of Derris urucu.

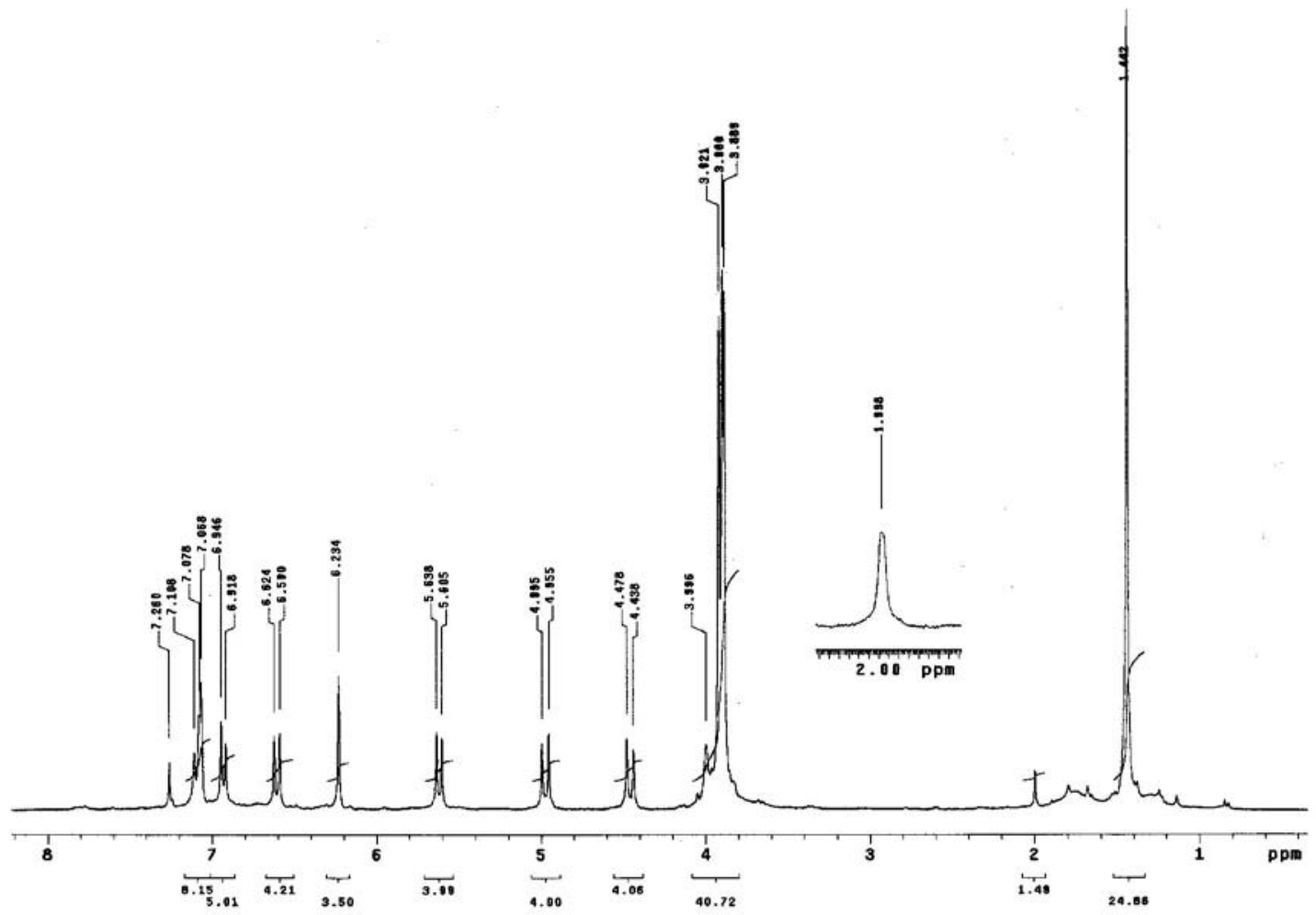

Figure S13. ${ }^{1} \mathrm{H}$ NMR experiment (in $\mathrm{CDCl}_{3}, 300 \mathrm{MHz}$ ) of the compound $\mathbf{3}$ isolated from leaves of Derris urucu. 


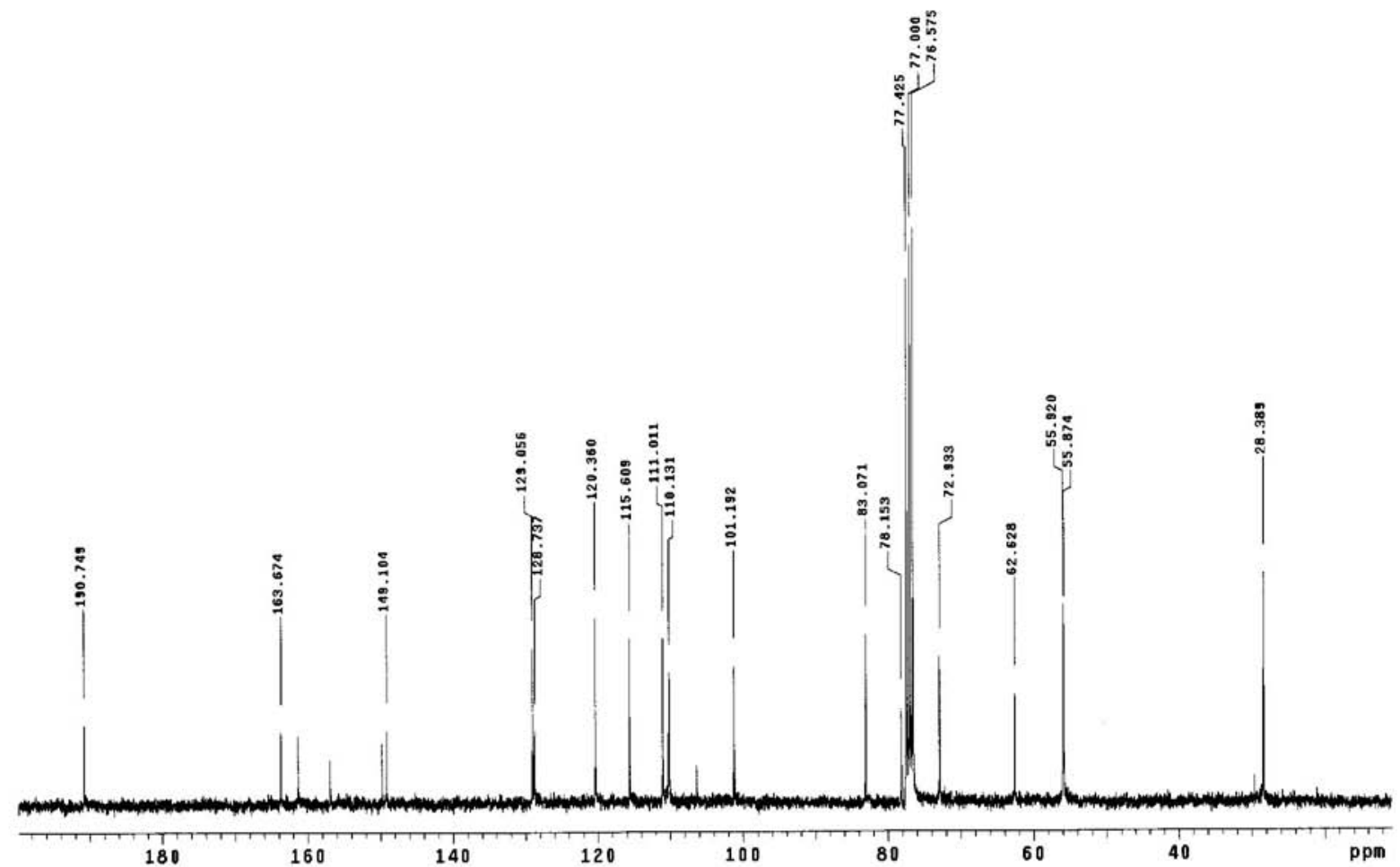

Figure S14. ${ }^{13} \mathrm{C}$ NMR spectrum (in $\mathrm{CDCl}_{3}, 75 \mathrm{MHz}$ ) of the compound 3 isolated from leaves of Derris urucu.

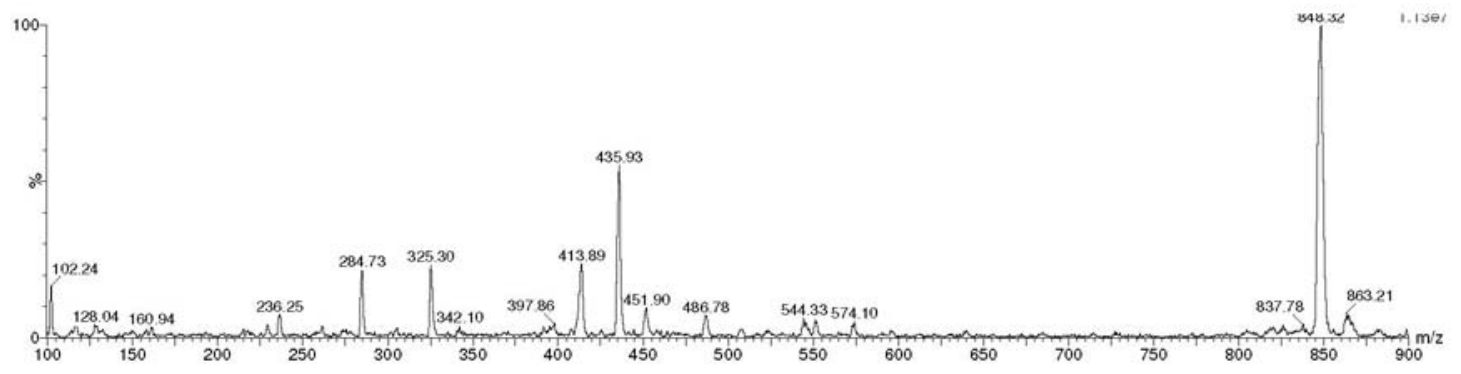

Figure S15. ESI mass spectrum of the compound $\mathbf{3}$ isolated from leaves of Derris urucu. 


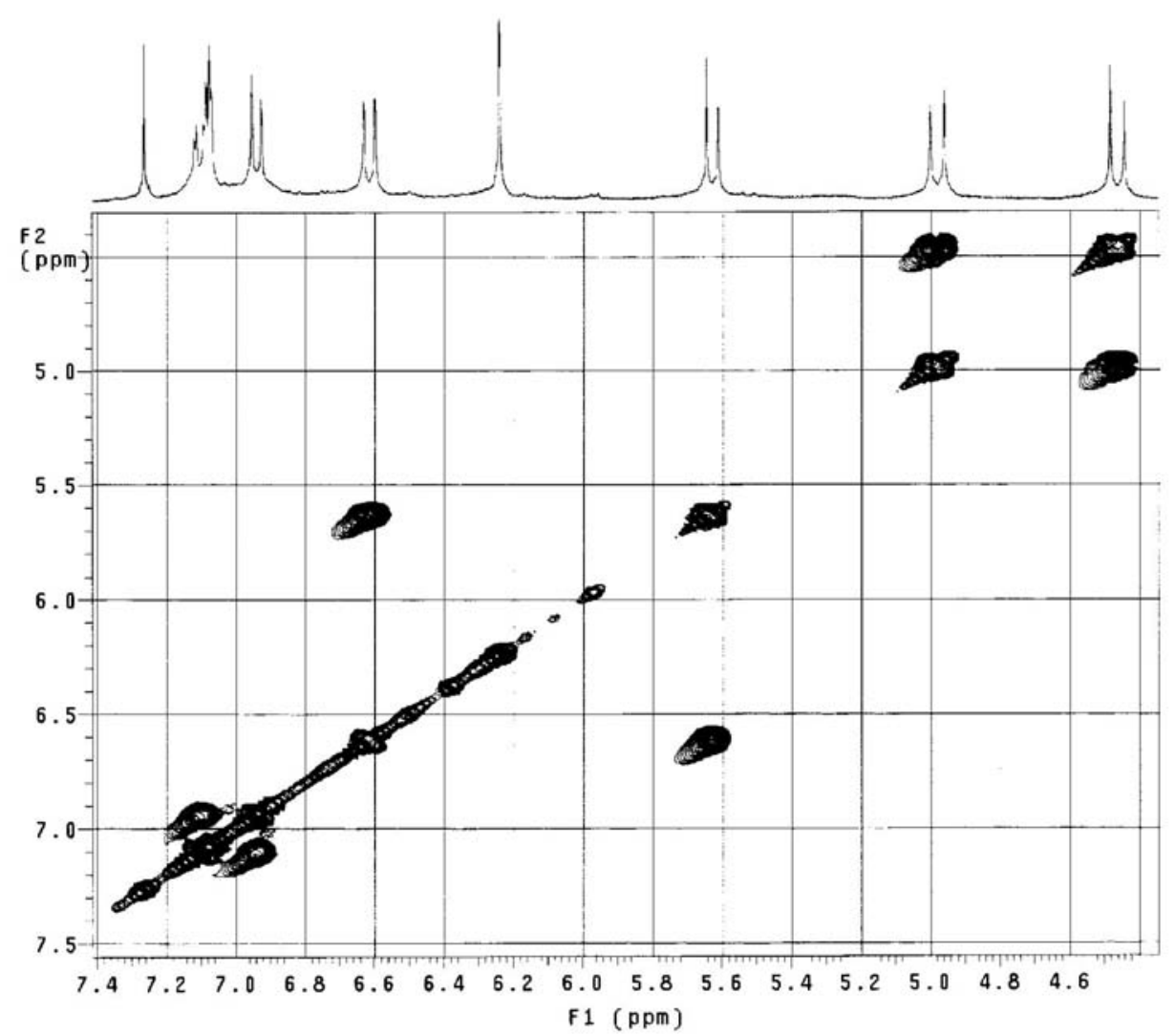

Figure S16. COSY NMR experiment (in $\mathrm{CDCl}_{3}, 300 \mathrm{MHz}$ ) of the compound 3 isolated from leaves of Derris urucu.

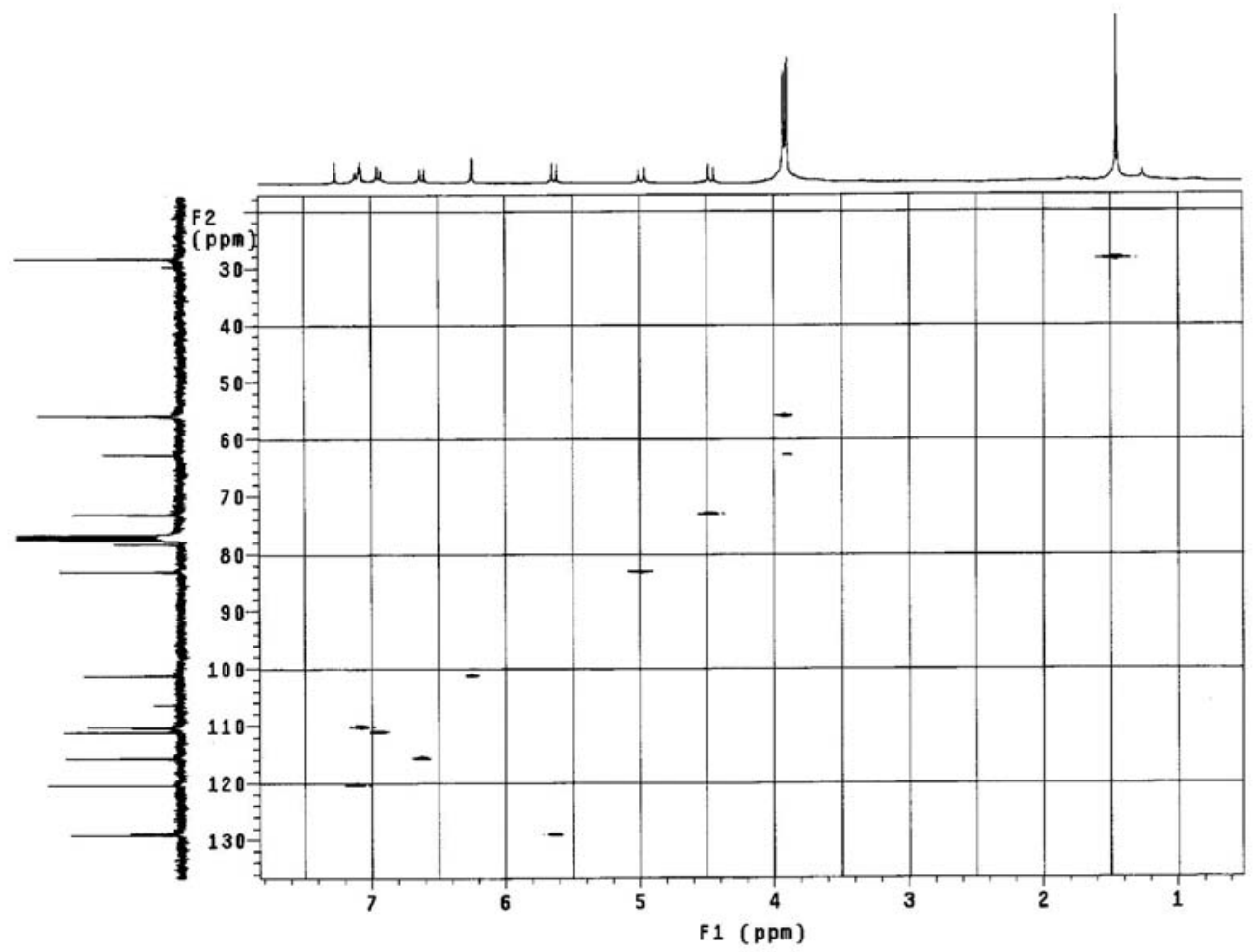

Figure S17. HETCOR NMR experiment (in $\mathrm{CDCl}_{3}, 300 \times 75 \mathrm{MHz}$ ) of the compound 3 isolated from leaves of Derris urucu. 


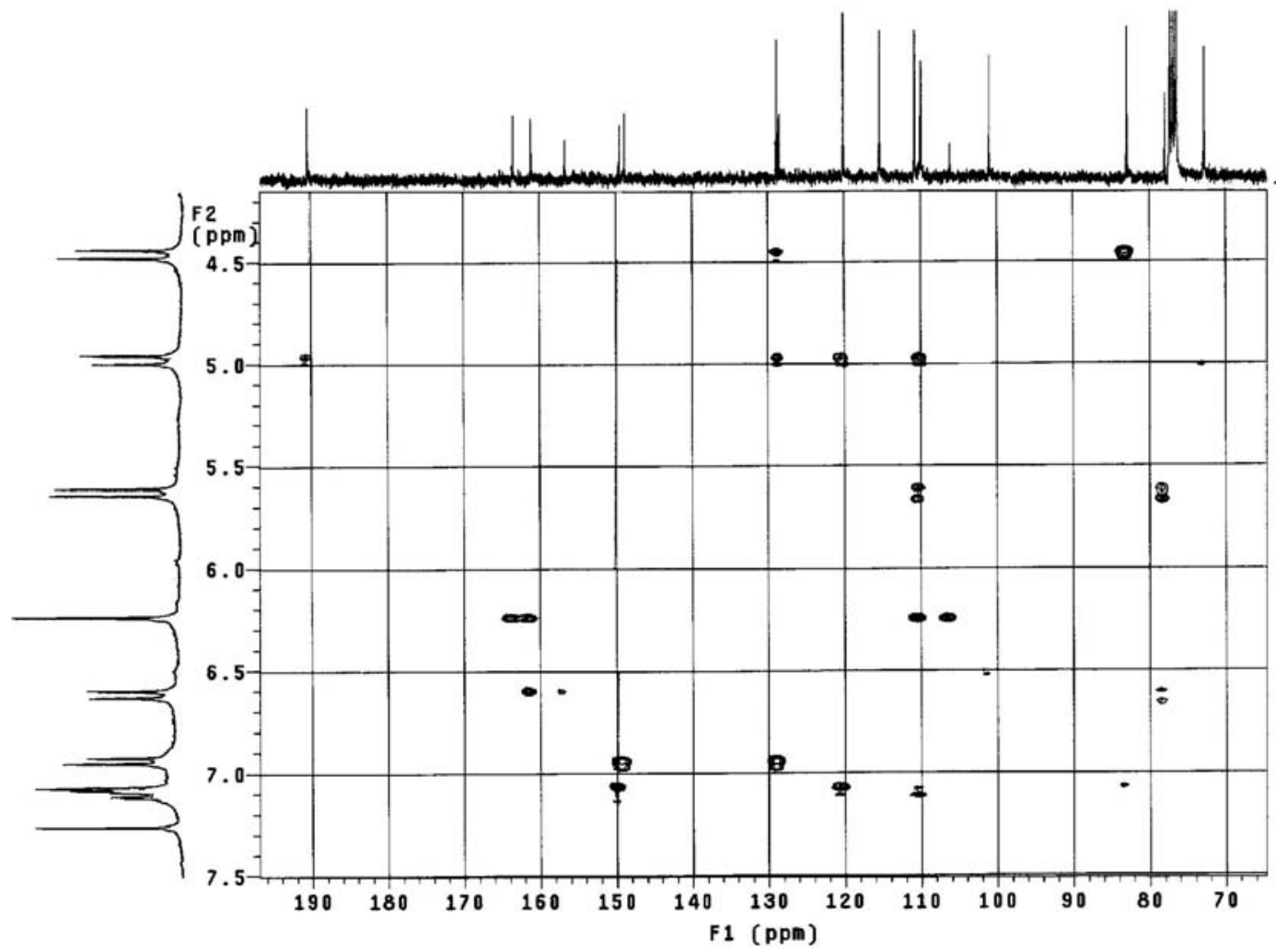

Figure S18. HMBC NMR experiment (in $\mathrm{CDCl}_{3}, 300 \times 75 \mathrm{MHz}$ ) of the compound 3 isolated from leaves of Derris urucu.

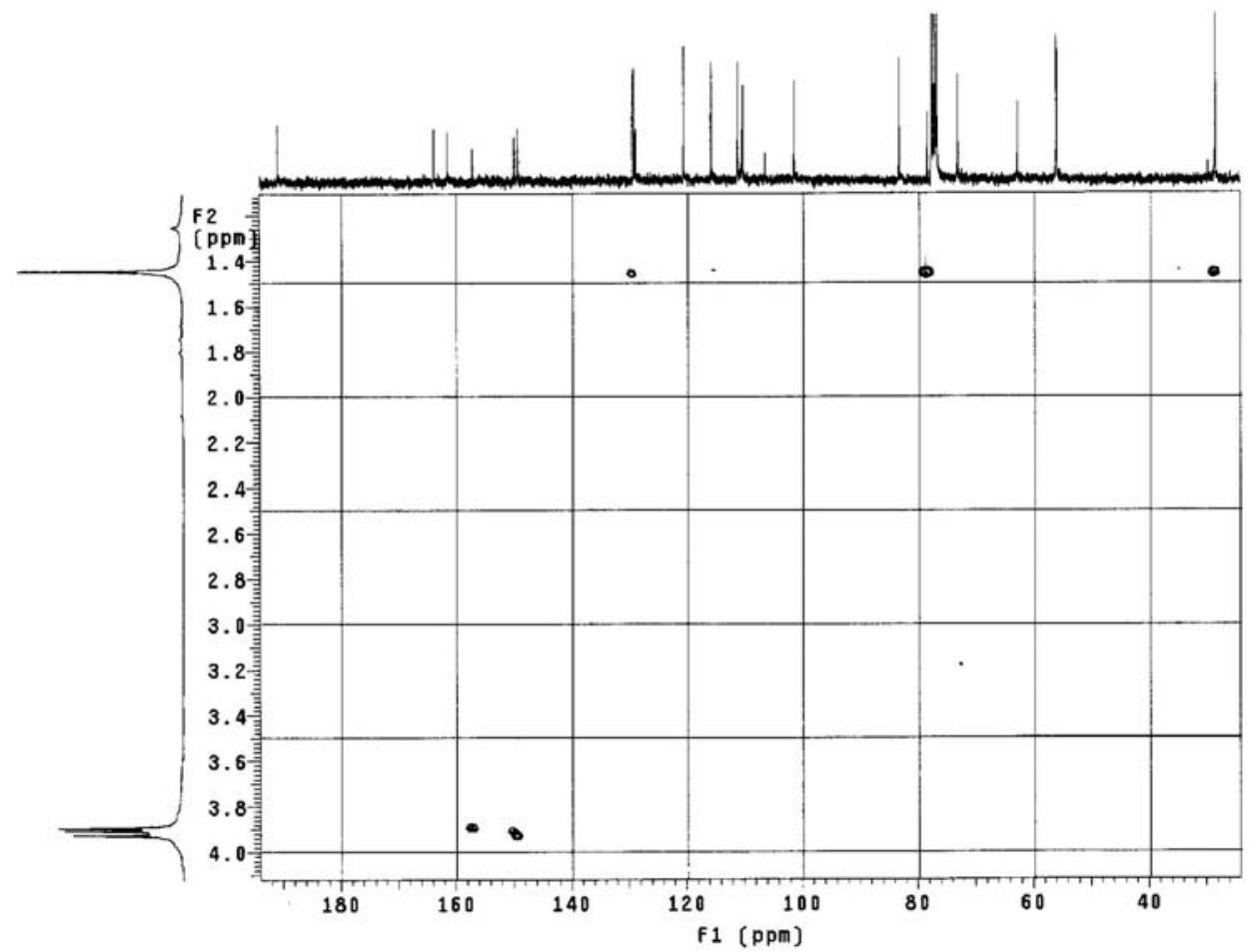

Figure S19. HMBC NMR experiment of the compound 3 (expansion). 


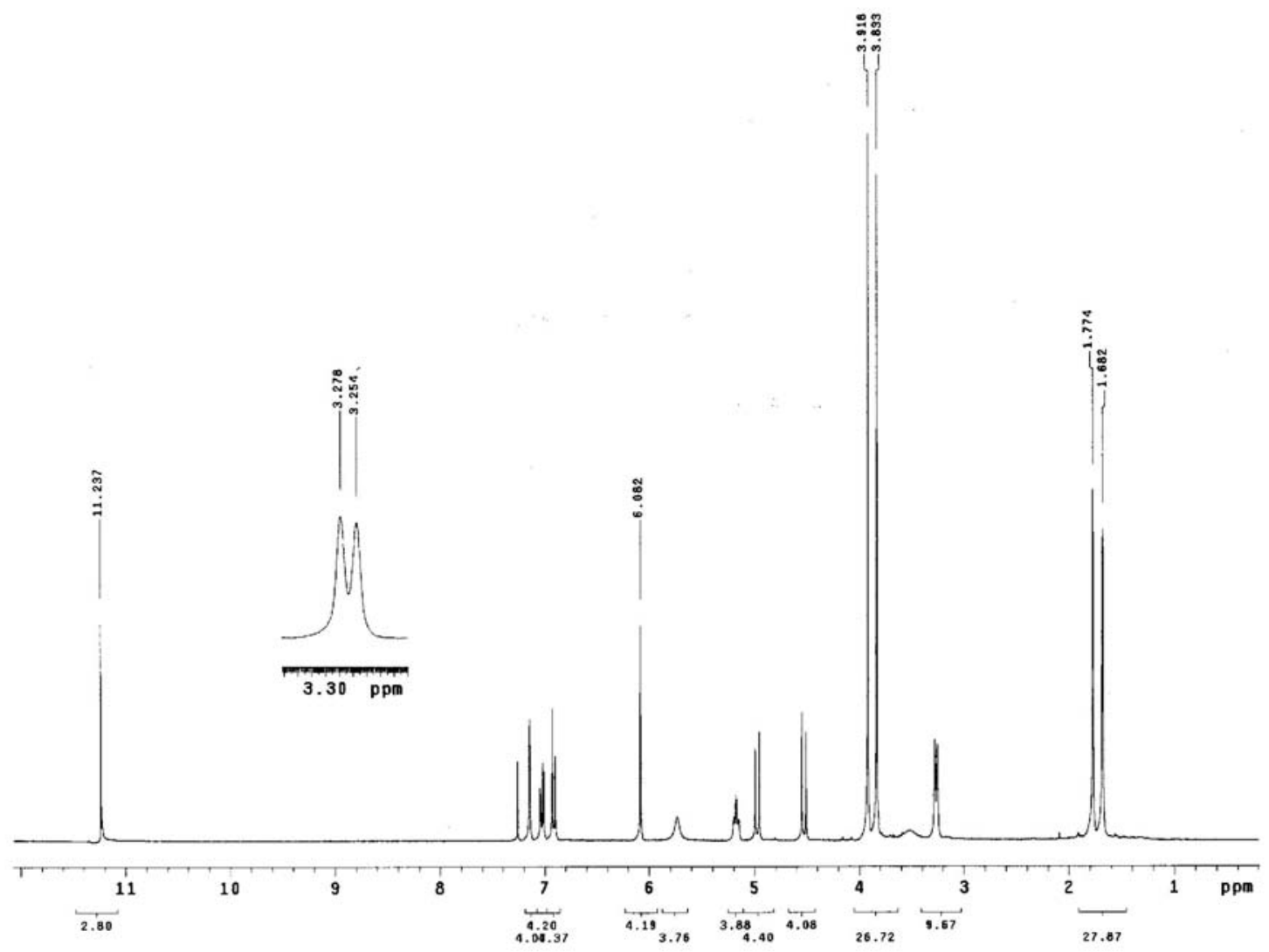

Figure S20. ${ }^{1} \mathrm{H}$ NMR experiment (in $\mathrm{CDCl}_{3}, 300 \mathrm{MHz}$ ) of the compound 4 isolated from leaves of Derris urucu.

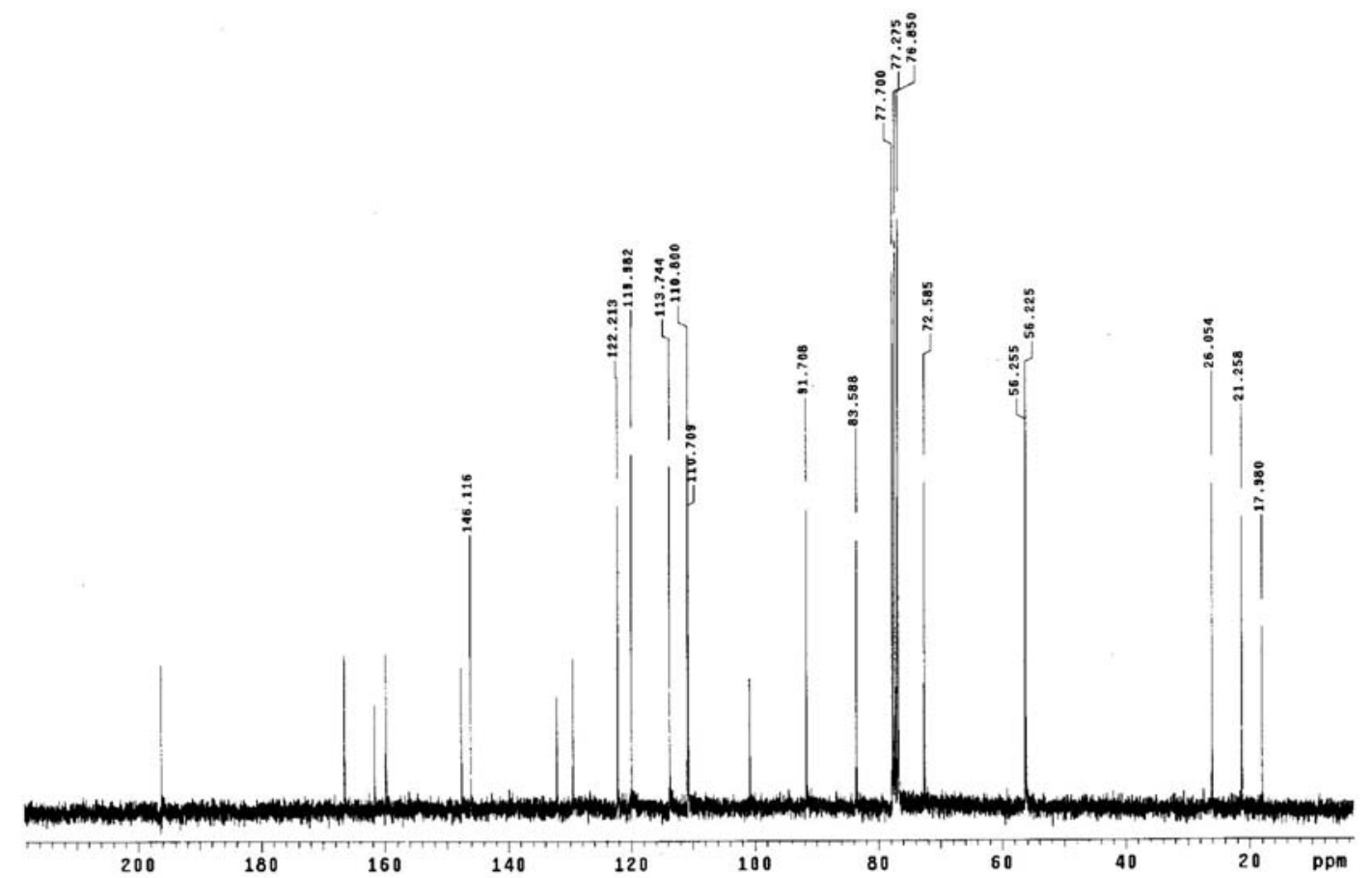

Figure S21. ${ }^{13} \mathrm{C}$ NMR spectrum (in $\mathrm{CDCl}_{3}, 75 \mathrm{MHz}$ ) of the compound $\mathbf{4}$ isolated from leaves of Derris urucu. 


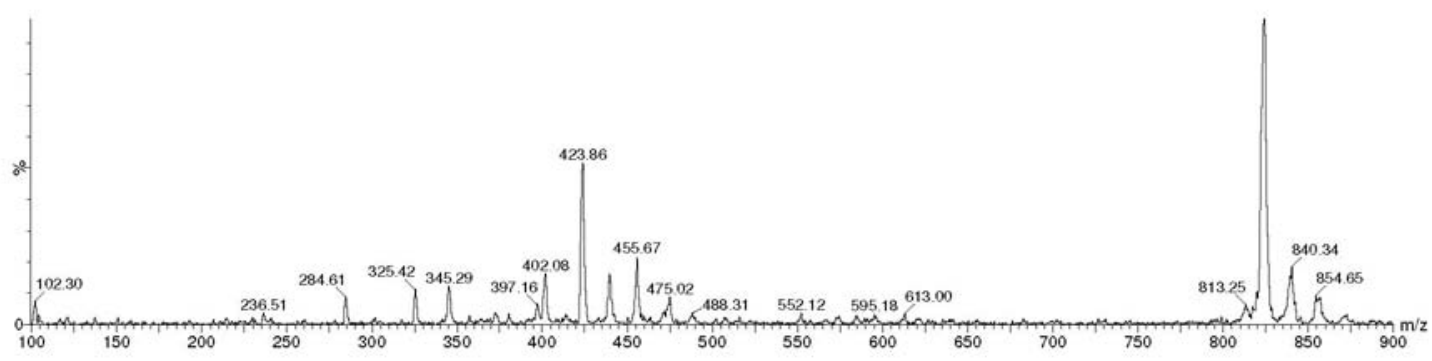

Figure S22. ESI mass spectrum of the compound $\mathbf{4}$ isolated from leaves of Derris urucu.

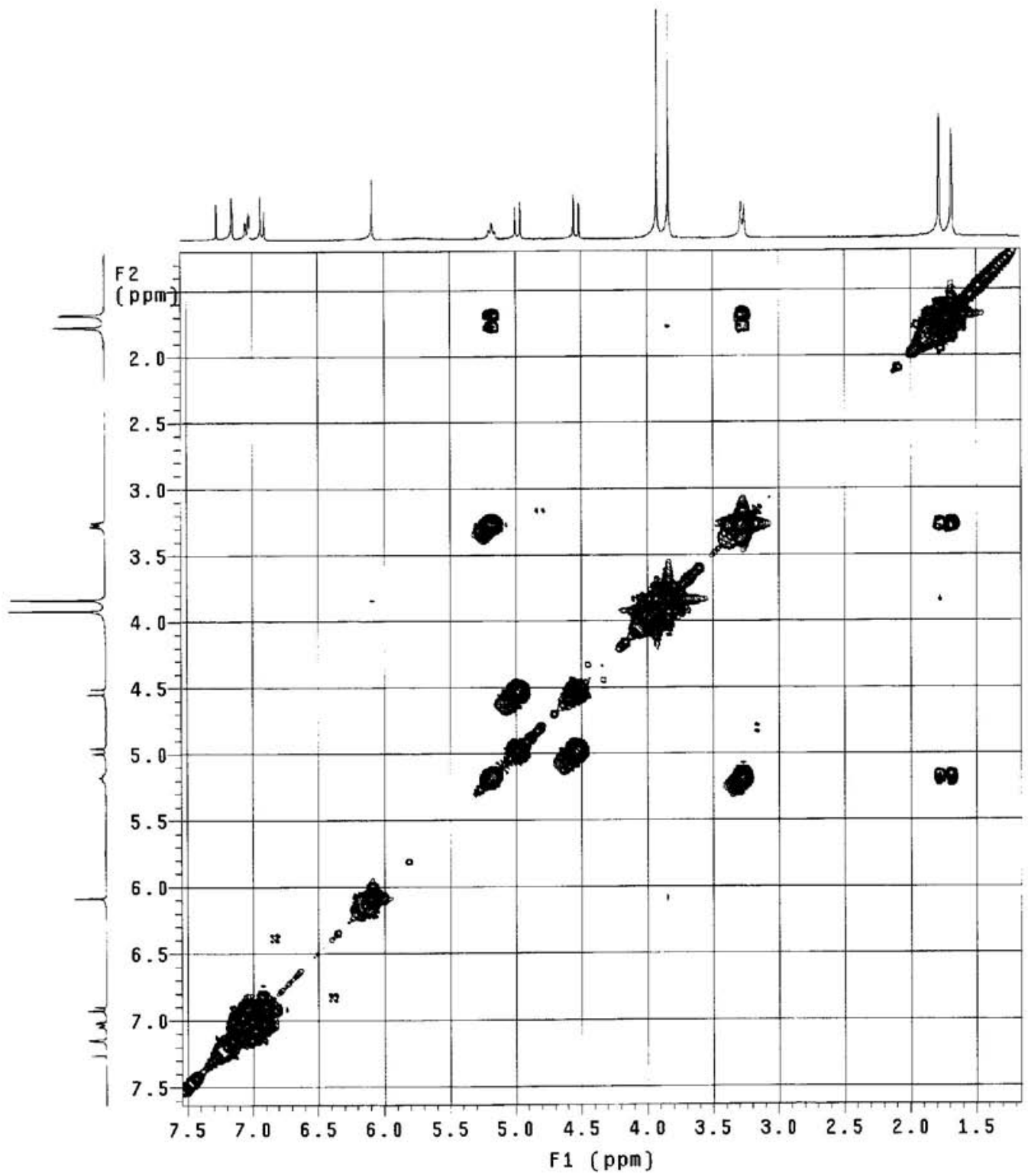

Figure S23. COSY NMR experiment (in $\mathrm{CDCl}_{3}, 300 \mathrm{MHz}$ ) of the compound 4 isolated from leaves of Derris urucu. 


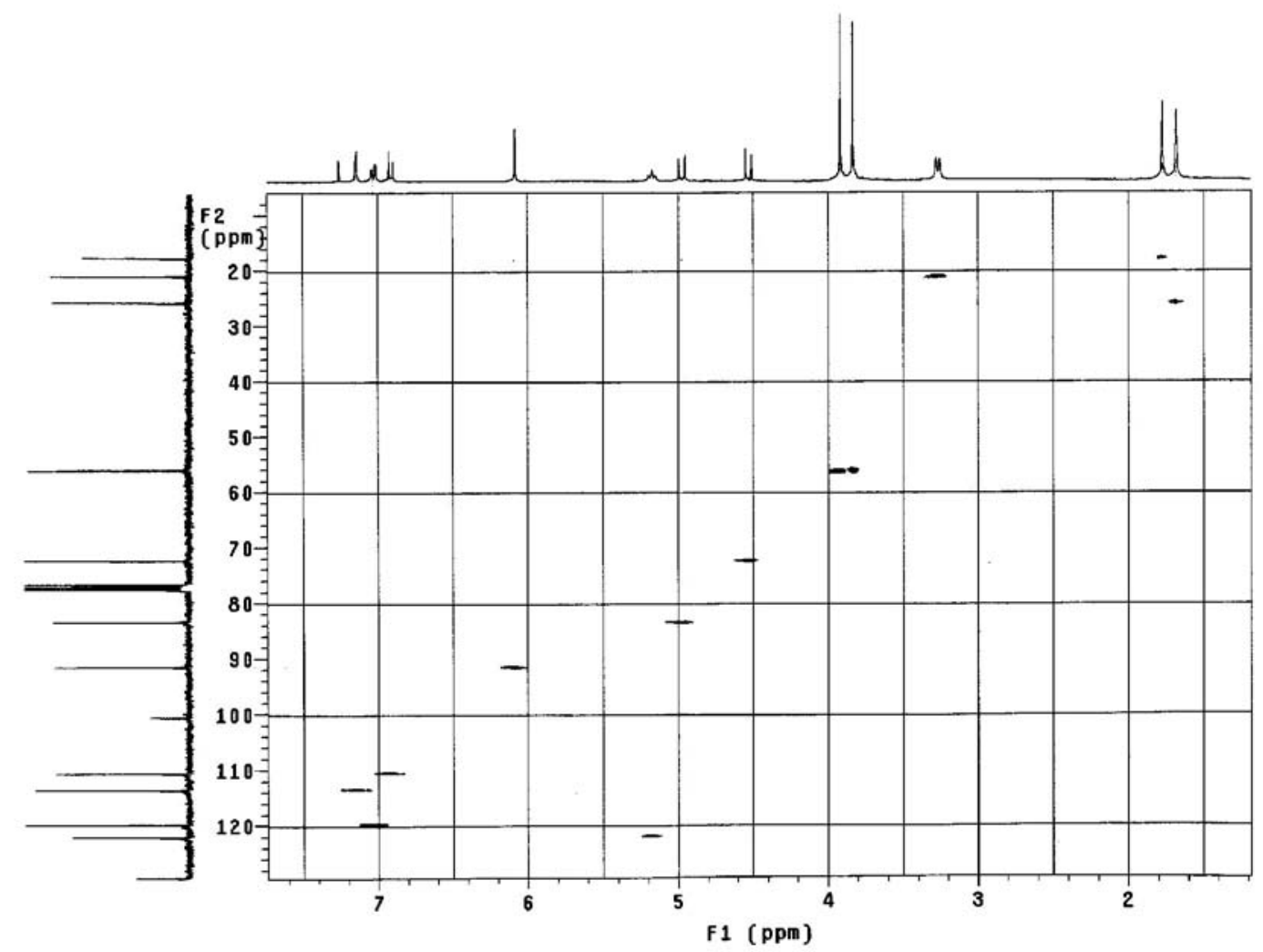

Figure S24. HETCOR NMR experiment (in $\mathrm{CDCl}_{3}, 300$ x $75 \mathrm{MHz}$ ) of the compound 4 isolated from leaves of Derris urucu.

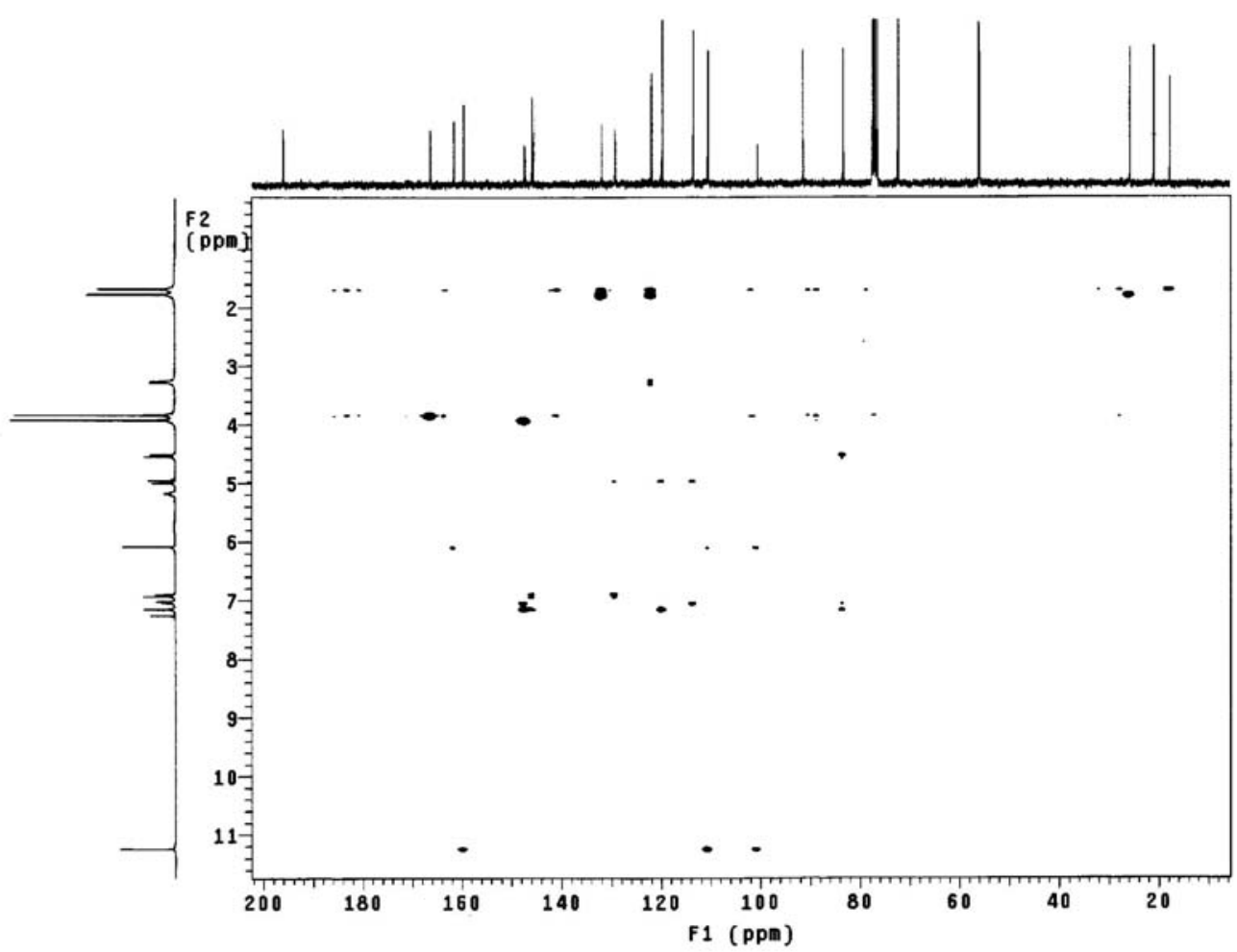

Figure S25. HMBC NMR experiment (in $\mathrm{CDCl}_{3}, 300 \times 75 \mathrm{MHz}$ ) of the compound 4 isolated from leaves of Derris urucu. 


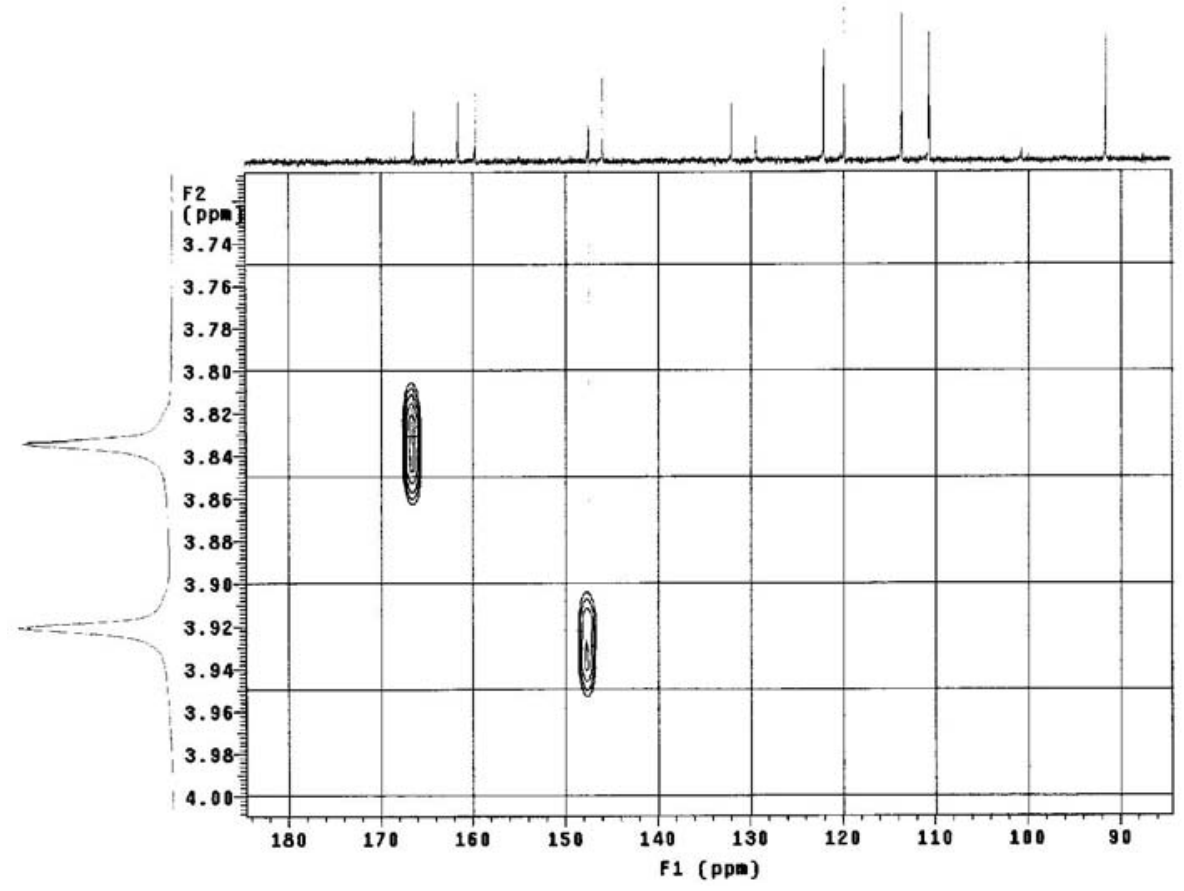

Figure S26. HMBC NMR experiment of the compound $\mathbf{4}$ (expansion).

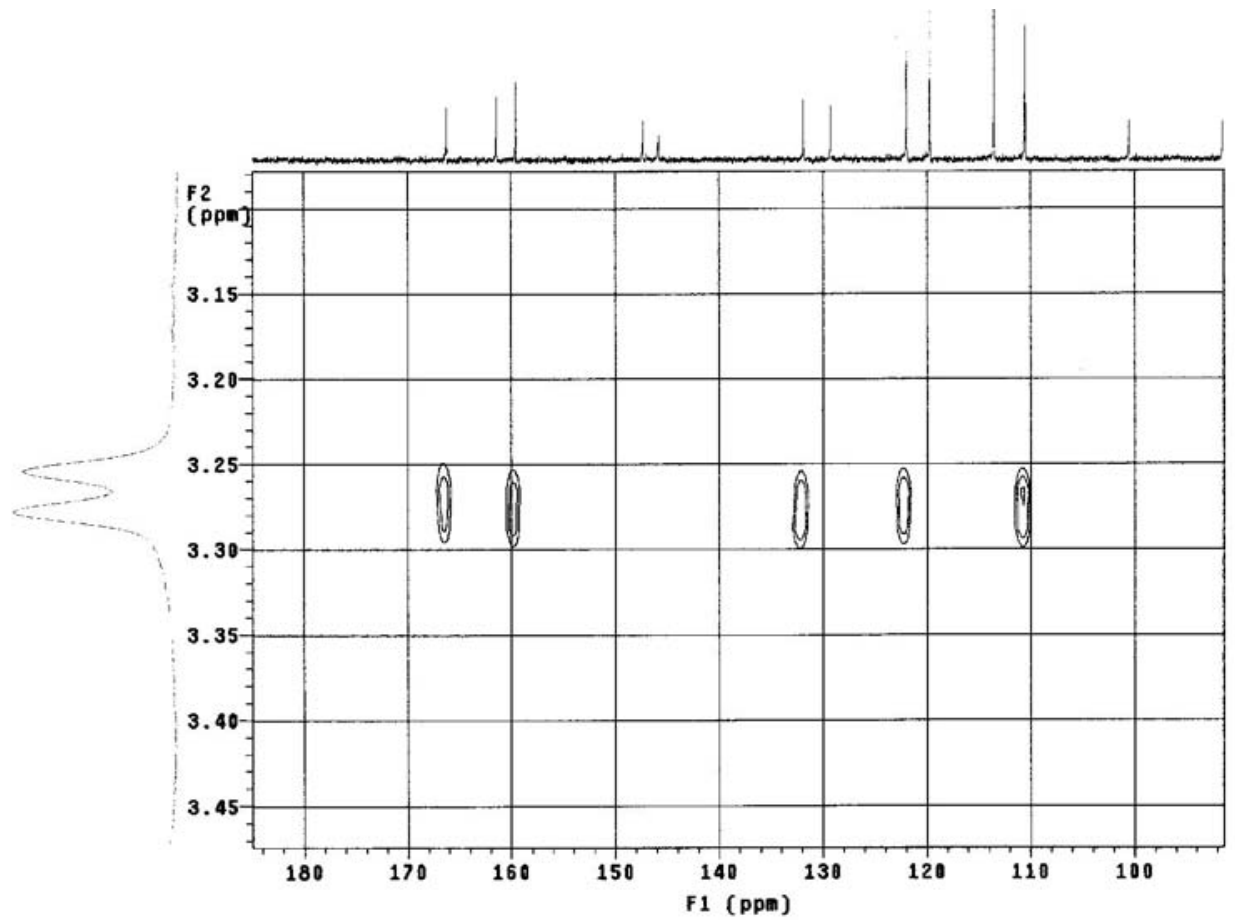

Figure S27. HMBC NMR experiment of the compound 4 (expansion). 